\title{
28. EOLIAN DEPOSITION ON THE ONTONG JAVA PLATEAU SINCE THE OLIGOCENE: UNMIXING A RECORD OF MULTIPLE DUST SOURCES ${ }^{1}$
}

\author{
Lawrence A. Krissek ${ }^{2}$ and Thomas R. Janecek ${ }^{3}$
}

\begin{abstract}
The record of eolian deposition on the Ontong Java Plateau (OJP) since the Oligocene (approximately $33 \mathrm{Ma}$ ) has been investigated using dust grain size, dust flux, and dust mineralogy, with the goal of interpreting the paleoclimatology and paleometeorology of the western equatorial Pacific. Studies of modern dust dispersal in the Pacific have indicated that the equatorial regions receive contributions from both the Northern Hemisphere westerly winds and the equatorial easterlies; limited meteorological data suggest that low-altitude westerlies could also transport dust to OJP from proximal sources in the western Pacific. Previous studies have established the characteristics of the grain-size, flux, and mineralogy records of dust deposited in the North Pacific by the mid-latitude westerlies and in the eastern equatorial Pacific by the low-latitude easterlies since the Oligocene. By comparing the OJP records with the well-defined records of the mid-latitude westerlies and the low-latitude easterlies, the importance of multiple sources of dust to OJP can be recognized.

OJP dust is composed of quartz, illite, kaolinite/chlorite, plagioclase feldspar, smectite, and heulandite. Mineral abundance profiles and principal components analysis (PCA) of the mineral abundance data have been used to identify assemblages of minerals that covary through all or part of the OJP record. Abundances of quartz, illite, and kaolinite/chlorite covary throughout the interval studied, defining a mineralogical assemblage supplied from Asia. Some plagioclase and smectite were also supplied as part of this assemblage during the late Miocene and Pliocene/Pleistocene, but other source areas have supplied significant amounts of plagioclase, smectite, and heulandite to OJP since the Oligocene. OJP dust is generally coarser than dust deposited by the Northern Hemisphere westerlies or the equatorial easterlies, and it accumulates more rapidly by 1-2 orders of magnitude. These relationships indicate the importance of the local sources on dust deposition at OJP. The grain-size and flux records of OJP dust do not exhibit most of the events observed in the corresponding records of the Northern Hemisphere westerlies or the equatorial easterlies, because these features are masked by the mixing of dust from several sources at OJP. The abundance record of the Asian dust assemblage at OJP, however, does contain most of the features characteristic of dust flux by means of the Northern Hemisphere westerlies, indicating that the paleoclimatic and paleometeorologic signal of a particular source area and wind system can be preserved in areas well beyond the region dominated by that source and those winds. Identifying such a signal requires "unmixing" the various dust assemblages, which can be accomplished by combining grain-size, flux, and mineralogic data.
\end{abstract}

\section{INTRODUCTION}

One of the major objectives of drilling on the Ontong Java Plateau (OJP) during Ocean Drilling Program (ODP) Leg 130 was to recover and investigate long-term and detailed short-term records of paleoclimate and paleoenvironments from an area that has remained in a near-equatorial setting through much of the Cenozoic (Kroenke, 1984; Kroenke, Berger, Janecek, et al., 1991). In pelagic depositional settings of the oceans, especially those similar to OJP that are located on bathymetric highs, far from major land masses, and in low to mid latitudes (Fig. 1), eolian processes are the dominant supplier of terrigenous particles to the underlying sediments (Pewe, 1981; Prospero, 1981; Pye, 1987; Chamley, 1989). These physical characteristics minimize the supply of terrigenous particles to OJP sediments by fluvial processes, ice rafting, and turbidity flows, leaving eolian processes as the dominant source of terrigenous input. The recovery of a relatively complete post-Oligocene record on OJP provides the opportunity to investigate long-term changes in the records of dust grain size, mass accumulation rate (MAR), and mineralogy, and to interpret those data in terms of the paleoclimatology and paleometeorology of OJP and the surrounding areas. This study examines the dust record from the Oligocene (approximately $33 \mathrm{Ma}$ ) to the present; a companion study (L.A. Krissek and T.R. Janecek, unpubl. data, 1992) examines a temporally detailed Pliocene and Quaternary dust record.

'Berger, W.H., Kroenke, L.W., Mayer, L.A., et al., 1993. Proc. ODP, Sci. Results, 130: College Station, TX (Ocean Drilling Program).

Department of Geological Sciences, Ohio State University, Columbus, OH 43210 , U.S.A.

${ }^{3}$ Ocean Drilling Program, Texas A\&M University, 1000 Discovery Drive, College Station, TX 77845-9547, U.S.A.

\section{The Oceanic Dust Record and Its Implications}

Over the past several decades, three major characteristics of eolian components in marine sediments have been examined in a number of studies: the mean dust grain size, the dust mass accumulation rate (MAR), and the dust mineralogy. Each of these characteristics responds to a distinct set of geologic, climatic, and meteorologic controls; the potential importance of each control on a particular characteristic depends upon the temporal and spatial scales of the record under study. For example, tectonically driven lithospheric plate motions have little effect on Quaternary dust records, but they become very important in understanding dust records that extend through the Cenozoic (Rea, 1989).

Because dust grain size, MAR, and mineralogy respond to a number of environmental and climatic conditions that exist at the time of dust formation, transport, and deposition, these characteristics of ancient dust components in marine sediments have been widely used to infer paleoclimatologic and paleometeorologic histories. For example, the mean grain size has been used as a proxy for wind intensity, with an increase in grain size interpreted to record a general increase in wind strength (Parkin, 1974; Parkin and Padgham, 1975; Janecek and Rea, 1985; Clemens and Prell, 1990). A quantitative relationship between wind intensity and dust grain size has not been well resolved, however. Wind intensity can change on short time scales (10-100 k.y.) in response to hemispheric or global climate (e.g., glacial/interglacial cycles), and on longer time scales ( $>500$ k.y.) in response to changes in global climate and global paleogeography (e.g., opening or closing of oceanic "gateways"; Kennett, 1982).

Dust MAR is generally used as a proxy for aridity in the continental source area of the dust (see discussion in Rea [1989] and references therein), with an increase in the MAR interpreted to record increased 


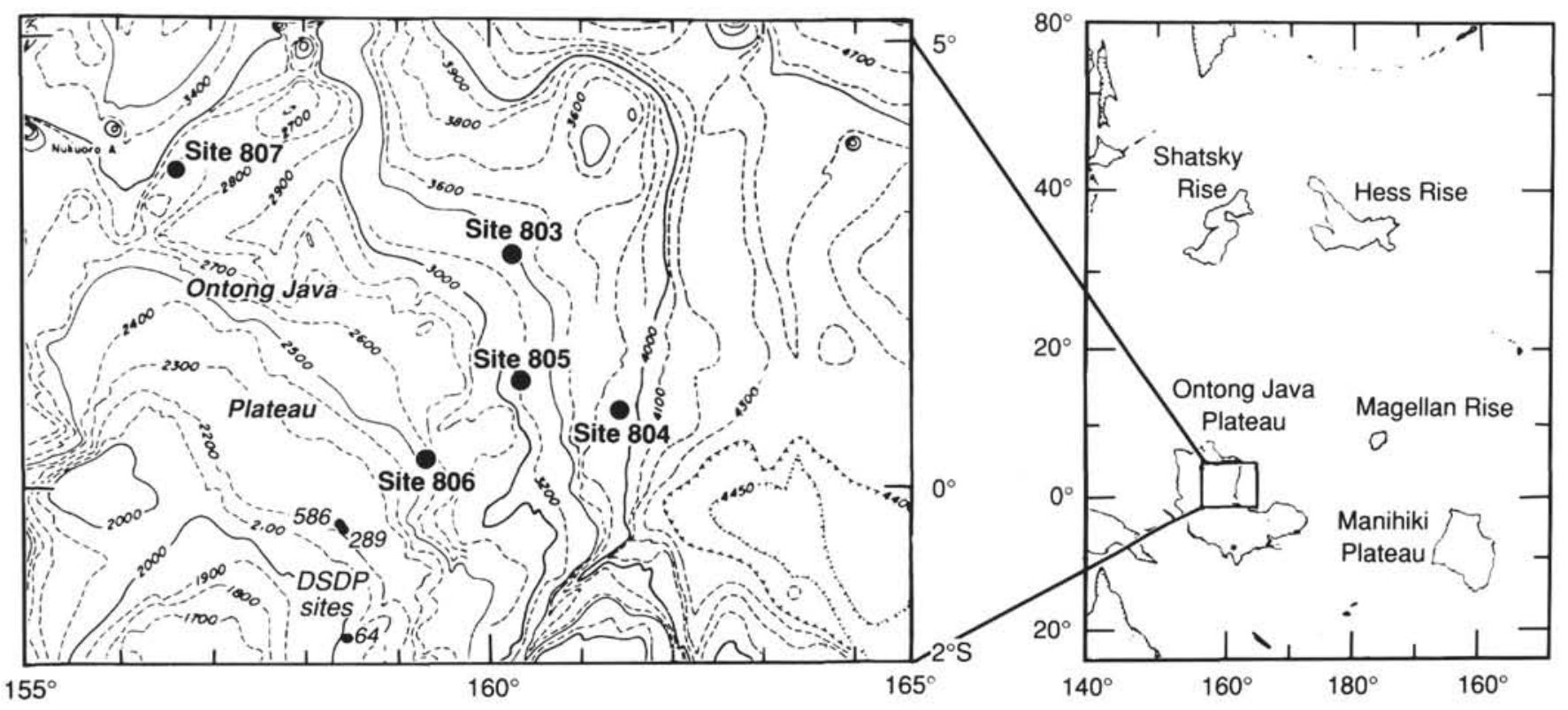

Figure 1. Location map of the Ontong Java Plateau and the Leg 130 sites.

aridity. More recently, however, Pye (1989) has demonstrated that dust will become more available in a source area as the climate changes either from semiarid to arid (increasing aridity) or from hyperarid to arid (decreasing aridity). The dust flux at a particular location can also vary if changes in atmospheric circulation patterns result in a different source area supplying dust to that site. On short time scales (10-100 k.y.), atmospheric circulation patterns may respond to changes in hemispheric or global climate (e.g., glacial/interglacial cycles), whereas circulation patterns respond on longer time scales ( $>500 \mathrm{k} . \mathrm{y}$.) to tectonic events such as mountain building (Rea, 1989). An additional complication in interpreting a long time-scale record of dust MAR is that lithospheric plate motions can move a site from the influence of one major wind belt into the influence of a second major wind belt; if the climates are significantly different in the upwind continental source regions for the two wind belts, then a change in dust MAR will reflect the migration history of the site, as well as changing climate within a source region or changing wind patterns.

The mineralogy of the total dust component is determined by the lithologies and weathering conditions present in the continental source regions (a response to source characteristics), the grain size of the dust (a response to wind strength), and the relative importance of dust contributed from each potential continental source (a response to source aridity and wind patterns). Most studies of dust mineralogy to date have minimized the effect of grain size by examining only the finest fraction (grains with diameter $<2 \mu \mathrm{m}$ ), although Krissek and Clemens (1991) examined the mineralogy of the total dust component at ODP Site 722 in the Arabian Sea. Studies of the total dust component (Krissek and Clemens, 1991) and the fine dust $(<2 \mu \mathrm{m}$; Debrabant et al., 1991) in Arabian Sea sediments identified similar dust sources, although the presence of tectosilicates and carbonates in the total dust provided additional information about lithologies and locations of the source areas. Changes in dust mineralogy on short time scales (10-100 k.y.) have generally been interpreted to record gla$\mathrm{cial} /$ interglacial effects on either weathering conditions or source-area importance (aridity changes or wind pattern shifts; Leinen, 1989; Krissek and Clemens, 1991). Mineralogic changes on longer time scales (>500 k.y.) have generally been interpreted to record changes in one or more of the following: outcrop geology of the source areas caused by erosion, volcanism, or orogeny; source-area importance caused by global shifts in climate or atmospheric circulation; and source-area importance caused by migration of a site out of the influence of one wind belt and into the influence of another (e.g., Schramm, 1989).

\section{The Ontong Java Plateau and Its Geologic Setting}

The OJP presently extends from approximately $5^{\circ} \mathrm{N}$ to $9^{\circ} \mathrm{S}$ latitude (Kroenke, Berger, Janecek, et al., 1991), thereby lying under the influence of the northeasterly and southeasterly trade winds (Terada and Hanzawa, 1984). Sites occupied during ODP Leg 130 were concentrated on the northern edge of OJP, at latitudes of $1^{\circ}-4^{\circ} \mathrm{N}$. The geologic history of OJP and the surrounding areas is summarized by Kroenke (1984); of particular concern here is its history of lithospheric plate migrations, because those migrations may have placed OJP under the influence of several different wind regimes during the past 30 m.y. Hammond et al. (1975) used paleomagnetic data from DSDP Site 289 to demonstrate that OJP migrated northward at a rate of approximately $2.5 \mathrm{~cm} / \mathrm{yr}$ between 70 and $30 \mathrm{Ma}$, moving from approximately $10^{\circ} 36^{\prime} \mathrm{S}$ at $70 \mathrm{Ma}$ to an equatorial position at $30 \mathrm{Ma}$. The data from Site 289 do not provide information about OJP migration history since $30 \mathrm{Ma}$, but other studies (van Andel et al., 1975) have established a similar migration rate for the central Pacific since $30 \mathrm{Ma}$. Tectonic reconstructions by Yan and Kroenke (this volume) show that OJP has been located north of $10^{\circ} \mathrm{S}$ since $30 \mathrm{Ma}$ (Fig. 2). Although the exact details of OJP migration over the past 30 m.y. are not clear, OJP does appear to have remained within the realm of the modern-day trade winds throughout the time interval considered in this study.

\section{Modern Meteorology and Dust Characteristics of the Pacific}

The grain-size, MAR, and mineral/chemical compositions of modern aerosols and ancient dust of the Pacific, Atlantic, and Indian oceans have been examined in a number of studies; recent summaries of this work include Pewe (1981), Prospero (1981), Pye (1987), Chamley (1989), and Leinen and Sarnthein (1989). Of particular interest here is information about dust in the Pacific Ocean that can be used to interpret the dust records from OJP. The composition and flux of modern dust and its effect on the underlying sediments are best known from studies of material collected in the North Pacific and equatorial Pacific regions (Rex and Goldberg, 1958; Prospero and 
Bonatti, 1969; Rex et al., 1969; Windom, 1969; Duce et al., 1980; Blank et al., 1985; Uematsu etal., 1985; Arimoto et al., 1987; Prospero et al., 1989). The dispersal trajectories of the dust have been mapped from satellite observations and meteorological data (Merrill, 1989; Merrill et al., 1989). Taken together, these studies have demonstrated that dust derived from central Asia and transported within the troposphere by the prevailing westerlies is the predominant terrigenous component in surface sediments of the North Pacific; this dust is predominantly supplied during the spring, when storms most actively raise dust in the arid regions of central Asia. Dust trajectory studies by Merrill (1989) and Merrill et al. (1989) have demonstrated that the influence of Asian dust can extend southward into the zone of the northeast trade winds, and that low concentrations of Asian dust may even cross into the Southern Hemisphere. This distribution develops as Asian dust, initially carried eastward by strong flow in the troposphere, is entrained around subtropical anticyclones and descends into the surface trade winds. The implication of this transport path for our studies of OJP dust is that material derived from Asia can be supplied to the western equatorial Pacific, as demonstrated by the predominance of Asian dust in aerosols collected at Enewetak $\left(11^{\circ} \mathrm{N}\right.$, $162^{\circ} \mathrm{E}$; Duce et al., 1980 ).

Less information is available about dust transported solely within the equatorial easterlies, although Prospero and Bonatti (1969) reported spring dust concentrations over the eastern equatorial Pacific approximately equal to those from the equatorial mid-Pacific (Prospero, 1979). The sources for this dust were interpreted to be the deserts of northern Chile and Peru (for the southeast trades) and southwest Mexico (for the northeast trades). Arimoto et al. (1987) reported that the dust concentrations at American Samoa $\left(14^{\circ} \mathrm{S}\right.$, $170^{\circ} \mathrm{W}$ ) were between $1 \%$ and $10 \%$ of the Asian-dominated dust concentrations at Enewetak, and that they exhibited little seasonal variability. These data suggest that only a small amount of dust is transported from the Americas to the vicinity of OJP by the equatorial easterlies.

Direct studies of atmospheric aerosols and their dispersal paths have not been conducted on OJP, but additional dust may be supplied to OJP from nearby sources by variable near-surface winds. For example, Terada and Hanzawa (1984) state that equatorial westerlies are sometimes observed at elevations below $5 \mathrm{~km}$, and provide wind roses for surface winds in the tropics during January, May, and September. In the vicinity of OJP, the wind roses for January and May are dominated by flow from the east and northeast; the wind rose for September, however, also shows components of flow from the south and west. These winds could be responsible for transporting dust to OJP from the volcanic arc rocks exposed in New Guinea and the Solomon Islands.

\section{The Geologic Record of Dust Deposition in the Pacific}

Several good long-term records of atmospheric circulation are available from the North Pacific, including those from LL44-GPC3 (Janecek and Rea, 1983; Schramm, 1989) and DSDP Sites 576 and 578 (Janecek, 1985; Schoonmaker et al., 1985; Leinen, 1985; LeNotre et al., 1985; Rea et al., 1985; Schramm, 1989); these findings have been summarized by Rea (1989). Leinen (1989) has also presented useful information about the composition of dust supplied to the North Pacific from three different source areas during the late Quaternary. From these studies, the dust record of the Northern Hemisphere westerlies since approximately $33 \mathrm{Ma}$ can be characterized as follows:

1. Dust MAR increases gradually through much of the Neogene, with well-defined increases at LL44-GPC3 and Site 576 at approximately $21-23,15-16,8$, and $5 \mathrm{Ma}$. All records of the Northern Hemisphere westerlies exhibit a significant increase (as much as 1 order of magnitude) in MAR at approximately $2.4 \mathrm{Ma}$, which is attributed to the onset of Northern Hemisphere glaciation. This over- all pattern is explained as recording the general increase in Neogene aridity that accompanied polar cooling (Rea, 1989).

2. Dust grain size increases gradually from the Oligocene to the Holocene, with well-defined increases at LL44-GPC3 and Site 576 at approximately $30-37,10-20$, and $5 \mathrm{Ma}$. Grain size increases only slightly at the onset of Northern Hemisphere glaciation. This overall pattern is explained as recording a general increase in wind intensity accompanying the development of steeper thermal gradients through the Neogene.

3. Dust mineralogy includes quartz, illite, smectite, chlorite, plagioclase feldspar, and kaolinite. Within upper Quaternary sediments (Leinen, 1989), an illite-smectite-quartz assemblage was derived from loess in central Asia, a plagioclase-quartz-smectite-chlorite assemblage contains material derived from Asia and mixed with soil material from Japan, and an illite-chlorite-plagioclase assemblage was derived from northern Asia. Older sediments in the North Pacific generally have mineralogies much like that of the upper Quaternary deposits, although clay-sized material carried by the westerlies appears to have changed from relatively kaolinite/quartz-rich in the Paleogene to relatively plagioclase/chlorite/illite-rich in the Neogene (Schramm, 1989).

The record of dust transported by the northeasterly trades during the Cenozoic has not been examined in much detail. Clays and associated minerals in sediments at DSDP Site 462 in the Nauru Basin include mixed-layer clays, chlorite, and some kaolinite, quartz, and feldspar; the influence of nearby volcanism is recorded by the presence of volcaniclastic grains, Fe-rich smectite, and clinoptilolite (Kurnosov and Shevchenko, 1981). Older sediments recovered at sites further to the north record activity of the easterlies before the Miocene and indicate that the easterlies consistently supplied less dust than the westerlies (Janecek and Rea, 1983; Janecek, 1985). On the basis of limited data, Schoonmaker et al. (1985) conclude that dust supplied by the easterlies to sediments at DSDP Site 576 before approximately $20 \mathrm{Ma}$ was relatively quartz-poor and smectite-rich.

Long-term records of the activity of the southeast trade winds were examined at DSDP Sites 597-602, located on the flank of the East Pacific Rise (Bloomstine and Rea, 1986), and at Site 595 in the central South Pacific (Schramm and Leinen, 1987). Dust MARs in both areas are much lower than those in the North Pacific and are relatively uniform from the Oligocene to the present. Dust grain size at Site 598 increases in sediments younger than approximately $10.5 \mathrm{Ma}$, a change attributed to wind intensification that accompanied formation of Antarctic ice. None of these records from the Southern Hemisphere exhibit the marked changes in MAR or grain size found in PliocenePleistocene sediments of the North Pacific.

\section{METHODS}

The samples for this study were taken from Holes 803D, 805B, and $805 \mathrm{C}$ at an interval of approximately $4.5 \mathrm{~m}$ (two samples per core). Several studies (Gillette, 1974; Gillette et al., 1974; Gillette and Walker, 1977; Johnson, 1976, 1979) have demonstrated that the dust population in transport reaches equilibrium at a distance of approximately $1000 \mathrm{~km}$ from the dust source; because OJP lies beyond that distance from potential sources, the effects of differential dust transport to these two sites on OJP are considered to be minimal, and the records from these three holes were combined for this study. The samples from Hole 803D provided material with ages of approximately 0-14.8 and 19.4-34.1 Ma; samples from Hole 805B were used to examine the record at $14.1-22.7 \mathrm{Ma}$; and the samples from Hole $805 \mathrm{C}$ supplemented the Hole $803 \mathrm{D}$ samples over the age range from 23.1 to $29.4 \mathrm{Ma}$ (Appendix A). The samples were taken from the nannofossil ooze/chalk to foraminifer nannofossil ooze/chalk that forms lithologic Unit I at each of the respective holes (Kroenke, Berger, Janecek, et al., 1991). 
A

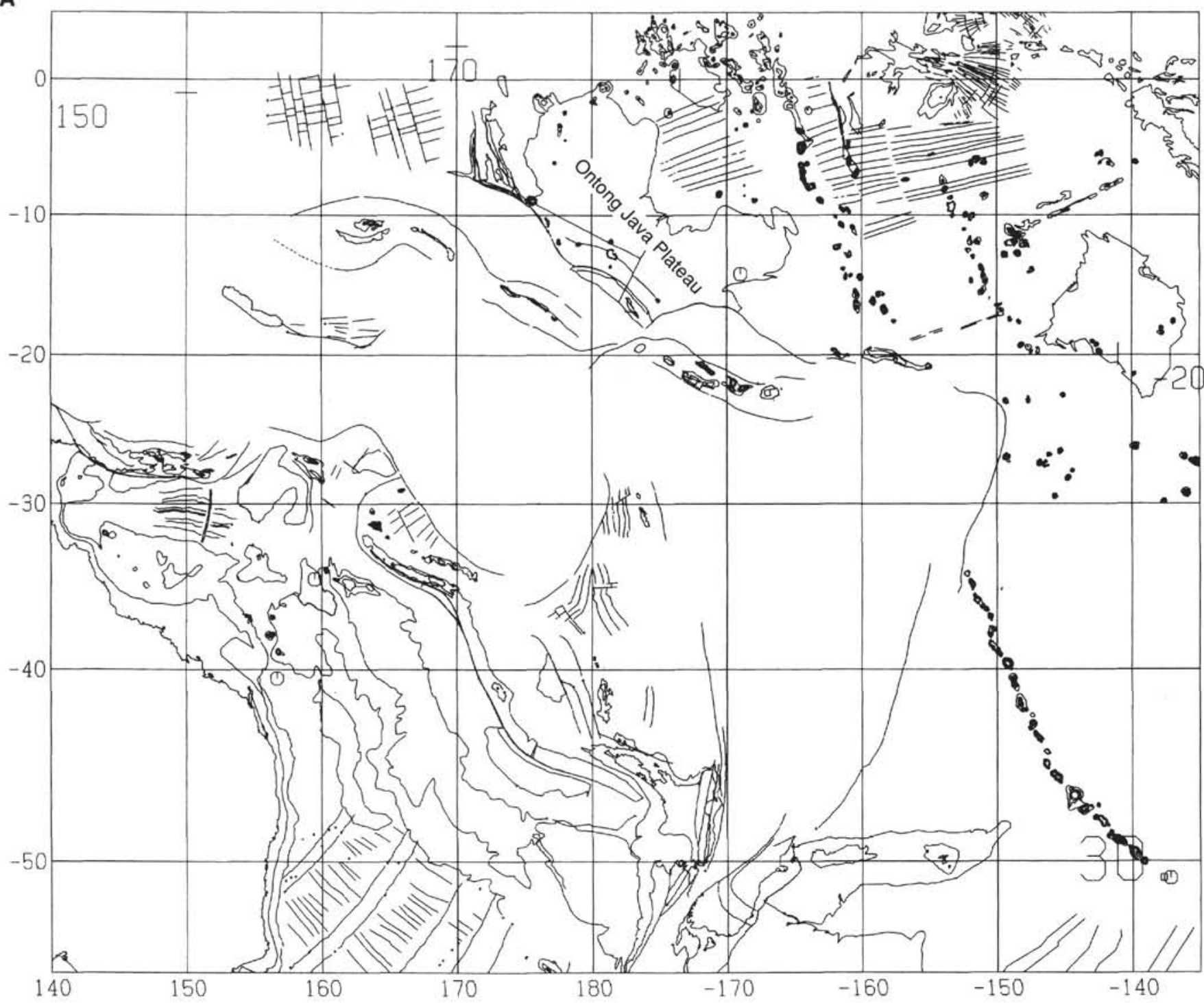

Figure 2. Tectonic reconstructions of the western equatorial Pacific at $30 \mathrm{Ma}$ (A) and $0 \mathrm{Ma}$ (B) (from Yan and Kroenke, this volume). The Ontong Java Plateau was located near the equator throughout the past $30 \mathrm{~m} . y$., in the region influenced by the modern equatorial easterlies.

\section{Terrigenous Abundance}

The abundance of terrigenous material was determined by isolating the detrital mineral component through a series of chemical extractions and weighing it. The eolian component is isolated by treating the samples successively with buffered acetic acid to remove calcium carbonate; with buffered sodium dithionite-sodium citrate to remove iron oxides and hydroxides; with sodium hypochlorite to remove organic material; and with sodium carbonate to remove biogenic opal. The procedure is outlined in detail in Rea and Janecek (1981). These extractions, however, do not remove volcanogenic components.

\section{Eolian Grain Size}

Grain-size analysis of the eolian component was conducted on the 1-28 $\mu \mathrm{m}$ size fraction using an eight-channel Laser Sensor Technology, Inc., Lab-Tec 100ME particle-size analyzer. The Lab-Tec 100ME sweeps a focused laser beam at a constant velocity across particles suspended in a solution. The "transit time" of the beam across a particle is measured and is a function of the size of the particle. Complete information about the unit and the methodology used in this study are provided in Mazzullo and Graham (1988).

\section{Mineralogy}

The mineralogy of the eolian component was analyzed by powder $\mathrm{x}$-ray diffractometry (XRD), using the general procedures outlined by Krissek (1989). Approximately $100 \mathrm{mg}$ of the bulk residue that remained after the chemical extractions were weighed and mixed with $10 \%$ by weight boehmite $(\mathrm{AlOOH})$, which serves as an internal standard. The mixtures were back-loaded as powders into random mounts for XRD analysis. All slides were solvated with warm ethylene-glycol vapor for 8-12 hr immediately preceding analysis on a Philips diffractometer. Slides were scanned at a rate of $1^{\circ} 2 \theta / \mathrm{min}$ with $\mathrm{Ni}$-filtered $\mathrm{CuK}$-alpha radiation. Data were plotted on a stripchart recorder.

The $15-18 \AA$ smectite $(001), 10 \AA$ illite $(001), 7 \AA$ chlorite/kaolinite $(002 / 001), 6.11 \AA$ boehmite (020), $4.26 \AA$ quartz (100), $4.02 \AA$ plagioclase (201), and $3.04 \AA$ calcite (104) peaks were measured with 
B

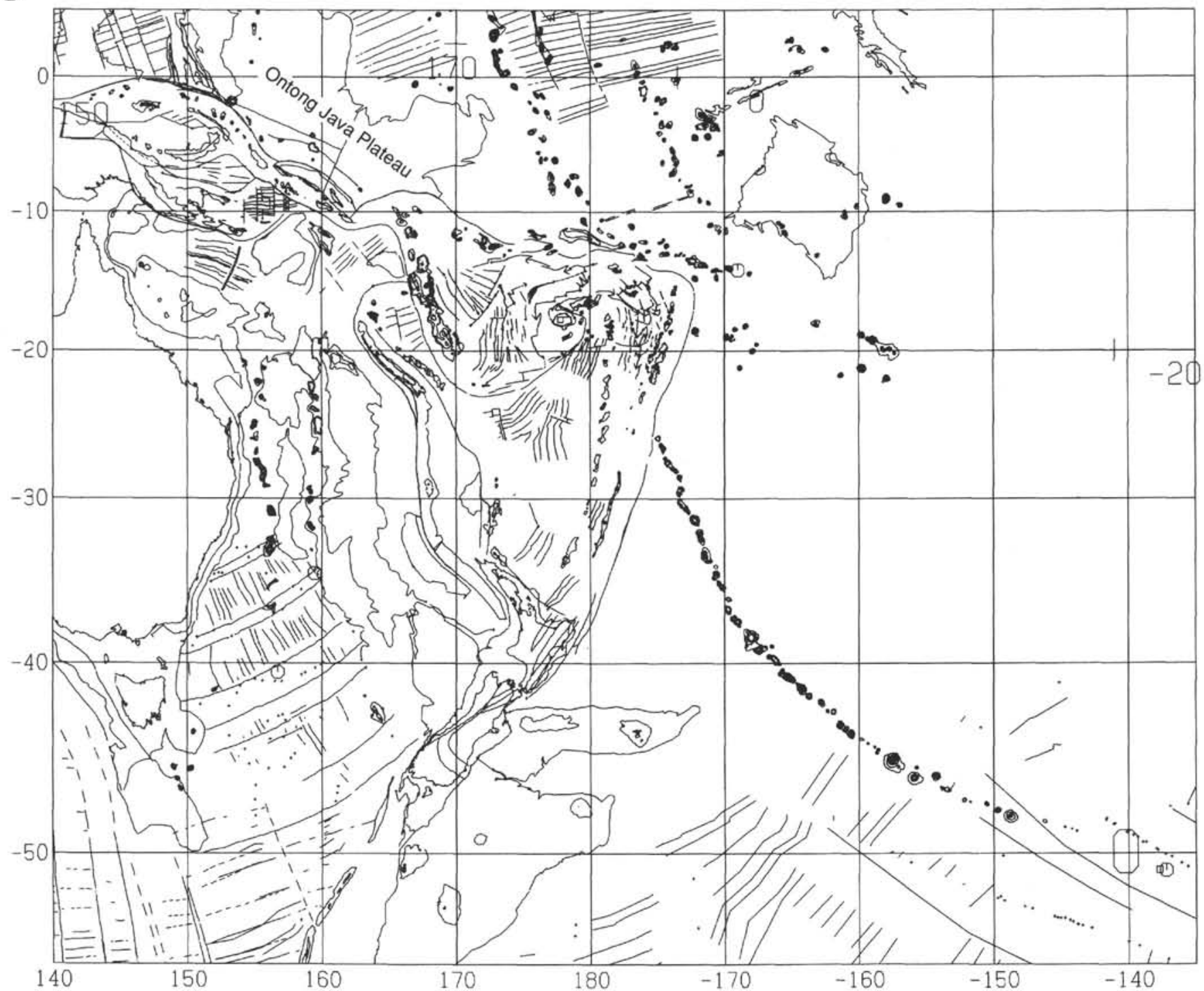

Figure 2 (continued).

a digitizing polar planimeter. The generally low intensity of the kaolinite/chlorite peak precluded further distinction of individual kaolinite and chlorite abundances. In addition to these peaks, which have been used successfully to indicate mineral abundances in previous studies (Krissek, 1984, 1989; Krissek and Clemens, 1991), three other peaks were also measured on these diffractograms. The first, a broad peak located at $4.66-4.13 \AA$, ranged from dominant to poorly defined on the diffractograms. When well defined, this peak was centered at approximately $4.38 \AA$ and tentatively identified as the (401) diffraction of the zeolite heulandite. This identification must be considered tentative, however, because other heulandite peaks that are generally more intense than this peak were not present on the diffractograms.

Two other peaks were also measured because the broad heulandite peak sometimes interfered with the $4.26 \AA$ quartz and $4.02 \AA$ plagioclase peaks. These are the $3.34 \AA$ quartz $(101)$ and $3.18-3.20 \AA$ plagioclase (002) peaks, which are not commonly used as indicators of mineral abundance because of interference with diffraction peaks of illite and potassium feldspar (K-feldspar), respectively. In this sample set, however, the low average intensity of the $10 \AA$ illite peak and the general correlation between higher intensity values of the two quartz peaks (Fig. 3A) indicate that the intensity of the $3.34 \AA$ peak is a valid indicator of quartz abundance. In a similar manner, the absence of other $\mathrm{K}$-feldspar peaks and the general correlation between higher intensity values of the two plagioclase peaks (Fig. 3B) indicate that the intensity of the $3.18-3.20 \AA$ peak is a valid indicator of plagioclase abundance.

By adding a uniform concentration of boehmite to all samples, the ratio of mineral peak area to boehmite peak area can be used to compare the abundance of a particular mineral between samples. These mineral/boehmite peak area ratios cannot be converted to absolute mineral abundances, however, so that the absolute abundances of two or more minerals cannot be compared. Analytical precision was evaluated by analyzing replicate slides of ten samples, and estimated uncertainties are presented in Table 1.

\section{Definition of Mineral Assemblages}

Previous mineralogical studies of the fine-grained terrigenous fraction of marine sediments have demonstrated the usefulness of principal components analysis (PCA, or "factor," analysis) for defining assemblages of minerals that covary through all or part of the 

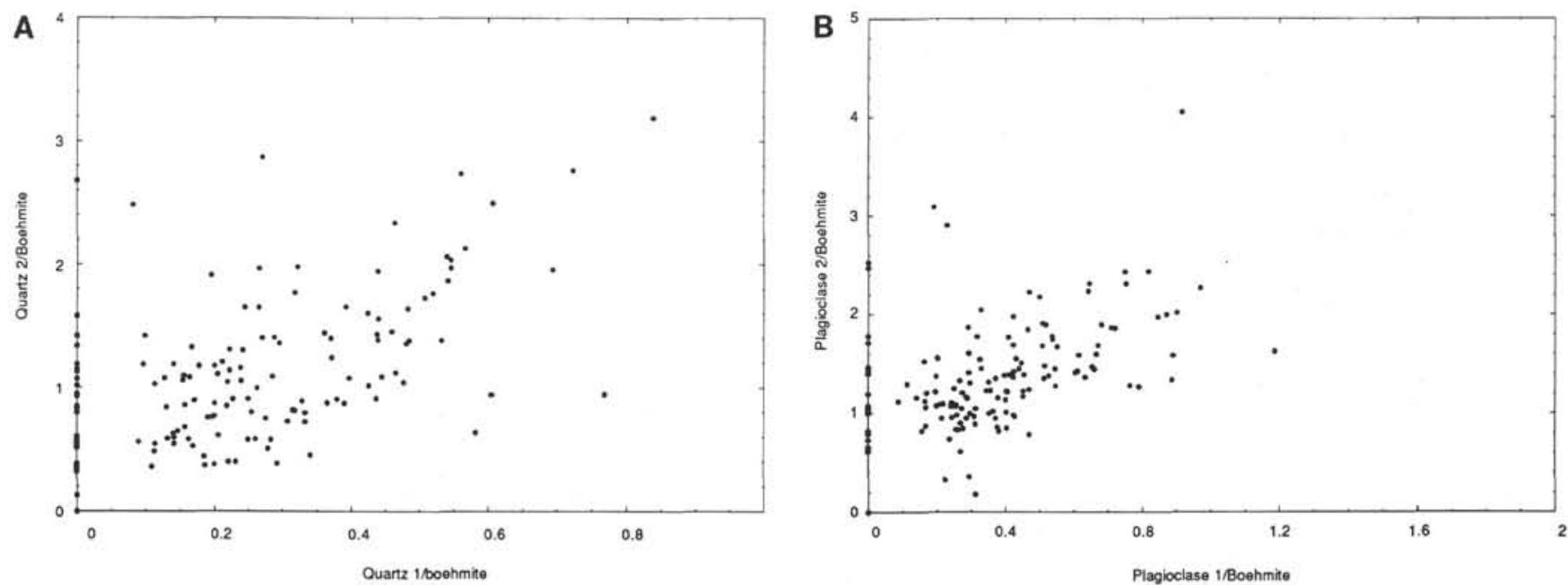

Figure 3. Scatter plots of XRD peak intensities. A. 4.26 quartz peak (Q1) vs. 3.34 quartz peak (Q2). B. 4.02 plagioclase (P1) vs. 3.18-3.20 plagioclase peak (P2).

interval under study (Leinen, 1989; Krissek and Clemens, 1991). The advantage of defining such assemblages is that the provenance of a polymineralic assemblage is generally more distinctive than the provenance of a single mineral (e.g., quartz). In this study, the PCA procedure available on "Data Desk" (Velleman and Velleman, 1988) was used to define assemblages of covarying minerals. This procedure extracts principal components ("factors") from the matrix of correlations between variables, thereby giving equal weight to each variable in the analysis. The factor matrix generated by a PCA is composed of coefficients whose magnitudes indicate the relative importance of each variable (mineral) within that factor (mineral assemblage). Differences in sign (positive vs. negative) of the factor matrix coefficients for two variables within a factor indicate a pattern of inverse correlation for those two variables. The PCA procedure on "Data Desk" does not provide coefficients that indicate the importance of each factor on individual samples; for this reason, stratigraphic profiles showing the importance of each factor downhole are not presented here.

Factor analysis was conducted on the entire OJP data set to define assemblages of minerals that covary throughout the time interval studied. Factor analysis was also conducted on mineral data from three subdivisions of the OJP record to investigate potential changes in the mineral assemblages through time. The boundaries of the time intervals chosen $(0-5,7-17$, and 17-34 Ma) were selected to (1) correspond with changes in the patterns of variation in the OJP mineral abundance profiles, (2) correspond with times of major change defined previously in studies of dust grain size and MAR elsewhere in the Pacific, and (3) avoid covariations that are artificially induced by an interval of incomplete calcite removal in OJP sediments 5-7 m.y. old. To prevent analytically questionable data points from strongly affecting the factor analysis results, all mineral/boehmite ratios $>5$ standard deviations from the mean for that mineral were removed before the factor analysis was performed.

\section{Linear Sedimentation Rates}

Linear sedimentation rates at Sites 803 and 805 were calculated from paleomagnetic and biostratigraphic datums reported in Kroenke, Berger, Janecek, et al. (1991). The datums, their positions in each hole, and the resulting sedimentation rates are listed in Table 2 and illustrated in Figures 4 and 5. At Hole 803D, these include 2 paleomagnetic datums and 11 biostratigraphic datums; the resulting sedimentation rates range from a minimum of $1.6 \mathrm{~m} / \mathrm{m} . \mathrm{y}$. at $14.9-19.5 \mathrm{Ma}$ to a maximum of $30.3 \mathrm{~m} / \mathrm{m}$.y. at $21.8-23.7 \mathrm{Ma}$. At Site 805 , datums from the depth intervals of interest in Holes $805 \mathrm{~B}$ and $805 \mathrm{C}$ were combined; the resulting data set consisted of four biostratigraphic datums, which gave sedimentation rates ranging from 13 to $21.3 \mathrm{~m} / \mathrm{m}$.y. for the period from 13.6 to $28.2 \mathrm{Ma}$. Sample ages (Appendix A) were calculated by linear interpolation of the appropriate sedimentation rates.

\section{Mass Accumulation Rates}

To calculate the mass accumulation rate (MAR) of the sediment, the actual dry mass of sediment per unit volume was multiplied by the linear sedimentation rate. Dry-bulk density values for this sample set were interpolated from shipboard physical properties data for Sites 803 and 805 (Kroenke, Berger, Janecek, et al., 1991), and the resulting MARs are plotted in Figure 5 and listed in Appendix A.

\section{RESULTS}

\section{Eolian Mass Accumulation Rates}

The abundance of terrigenous material ranges from $2 \%$ to $14 \%$ in sediments deposited since $34 \mathrm{Ma}$ at Sites 803 and 805, with an average value between $4 \%$ and $5 \%$ (Fig. 5). The mineralogic data presented below, however, indicate that sample pretreatment did not remove all of the calcite in the youngest sediments, especially those 4.85-7.6 m.y. in age. As a result, the peak in terrigenous abundance at 5-8 $\mathrm{Ma}$ is an artifact and does not indicate a real increase in terrigenous content.

Most of the terrigenous abundance values range from $4 \%$ to $8 \%$, whereas the bulk MAR values respond directly to changes in the sedimentation rate and range from essentially 0 to almost $4 \mathrm{~g} / \mathrm{cm}^{2} / \mathrm{k}$.y. (Fig. 5). The terrigenous MAR is the product of the bulk MAR and the terrigenous abundance; because the bulk MAR varies by more than a factor of 10 whereas the terrigenous abundance varies by much less, the terrigenous MAR closely follows the trend of the bulk MAR plot. Terrigenous MARs were generally between 100 and $300 \mathrm{mg} / \mathrm{cm}^{2} / \mathrm{k}$.y. in the Oligocene to early Miocene, with highest values at approximately $31-28$ and 24-22.5 Ma. Terrigenous MARs decreased during the early Miocene, particularly from 24 to $21 \mathrm{Ma}$, and they have remained generally $<100 \mathrm{mg} / \mathrm{cm}^{2} / \mathrm{k}$.y. since $20 \mathrm{Ma}$. The apparent peak in terrigenous MAR centered at approximately $6 \mathrm{Ma}$ is an artifact of incomplete calcite removal during sample processing.

\section{Eolian Grain Size}

The average grain size of the eolian component ranges from 5 to $13 \mu \mathrm{m}$ at Sites 803 and 805 (Fig. 5). Grain size averages between 8 and $9 \mu \mathrm{m}$ in Oligocene and lower Miocene sediments (34-21 Ma), 
Table 1. Estimates of analytical uncertainty in mineral abundance ratios.

\begin{tabular}{lcc}
\hline \multicolumn{1}{c}{ Mineral } & $\begin{array}{c}\text { Diffraction } \\
\text { peak }(\AA)\end{array}$ & Uncertainty \\
\hline Smectite & $14-17$ & \pm 0.9 \\
Illite & 10 & \pm 0.02 \\
Kaolinite/Chlorite & 7 & \pm 0.15 \\
Heulandite & 4.38 & \pm 1.2 \\
Quartz & 4.26 & \pm 0.16 \\
Plagioclase & 4.02 & \pm 0.13 \\
Quartz & 3.34 & \pm 0.17 \\
Plagioclase & $3.18-3.20$ & \pm 0.25 \\
Calcite & 3.04 & \pm 0.04 \\
\hline
\end{tabular}

Note: Values average absolute uncertainties in the mineral/ boehmite peak area ratios, based on replicate analyses of ten samples.

decreases to approximately $7 \mu \mathrm{m}$ in the lower to middle Miocene (21-10 Ma), and increases to an average of approximately $10 \mu \mathrm{m}$ in upper Miocene and younger sediments (10-0 Ma). The incomplete removal of calcite during pretreatment of the 5-8 Ma samples does not have an obvious effect on the grain-size signal for that interval.

\section{Mineralogy of the Eolian Component}

Mineral/boehmite peak area ratios are plotted in Figure 6 and listed in Appendix B. High calcite/boehmite ratios (Fig. 6A) are concentrated in the interval 5-8 Ma, reflecting incomplete calcite removal during sample pretreatment. Other non-zero values are scattered throughout the remainder of the profile, but calcite abundances significantly dilute abundances of the other minerals only in the interval 5-8 Ma.

Smectite has the largest average mineral/boehmite peak area ratio of the minerals identified in this study (Fig. 6B); the smectite/ boehmite ratio is consistently larger than 2 and averages between 4 and 5 for the entire data set. The smectite record shows no long-term trend, but it does exhibit several shorter term excursions in the lower to middle Miocene that are larger than the analytical uncertainty. The most obvious of these excursions is the short-lived increase in smectite content in the middle Miocene, centered at approximately $14 \mathrm{Ma}$.

The record of heulandite (zeolite) abundance (Fig. 6C) exhibits a relatively uniform baseline value, with higher abundances scattered throughout the interval studied. The higher abundances appear to cluster in the lower Oligocene (32-29 Ma), the lower to middle Miocene (23-14 Ma), and the upper Miocene to upper Pliocene (7-2 Ma).

The two records of plagioclase/boehmite peak area ratios (Figs. $6 \mathrm{D}-6 \mathrm{E})$ are similar through most of the section studied but exhibit slightly different patterns in the youngest sediments. Both plagioclase records are high in the Oligocene and decrease into the lower Miocene (approximately $20 \mathrm{Ma}$ ). In both records, however, this general decrease is interrupted by significantly increased plagioclase content in the upper Oligocene (approximately $27 \mathrm{Ma}$ ). Plagioclase abundances remain consistently low from the lower Miocene to at least the lower Pliocene. In sediments younger than the lower Pliocene, the $3.18 \AA$ plagioclase contents increase significantly, whereas the $4.02 \AA$ plagioclase record shows no significant change over the same interval. Because of the greater intensity of the 3.18-3.20 $\AA$ plagioclase peak and reduced interference effects on it relative to the $4.02 \AA$ peak, the increase in plagioclase content since the early Pliocene is considered to be real.

The two records of quartz/boehmite peak area ratios (Figs. 6F-6G) are very similar throughout the section studied. Quartz abundance is low in the Oligocene and increases gradually through the upper Oligocene and lower Miocene to a maximum in the middle Miocene (approximately $15 \mathrm{Ma}$ ). Quartz abundances then decrease through the remainder of the middle Miocene and part of the upper Miocene, before increasing dramatically (by a factor of approximately 4)
Table 2. Age datums, their depths, and resultant sedimentation rates at Holes 803D, 805B, and 805C.

\begin{tabular}{|c|c|c|c|}
\hline Event & $\begin{array}{l}\text { Depth } \\
\text { (mbsf) }\end{array}$ & $\begin{array}{l}\text { Age } \\
(\mathrm{Ma})\end{array}$ & $\begin{array}{c}\text { LSR } \\
(\mathrm{cm} / \mathrm{k} . \mathrm{y})\end{array}$ \\
\hline \multicolumn{4}{|l|}{ Hole 803D: } \\
\hline Top section & 0.00 & 0.0 & \\
\hline Olduvai $(0)$ & 17.60 & 1.9 & 9.4 \\
\hline Mammoth $(\mathrm{O})$ & 36.50 & 3.2 & 14.5 \\
\hline LO D. quinqueramus (N) & 69.85 & 5.0 & 18.3 \\
\hline LO D, hamatus $(\mathrm{N})$ & 174.35 & 8.7 & 28.2 \\
\hline FO G. peripheroacuta $(\mathrm{F})$ & 239.15 & 14.9 & 10.5 \\
\hline LO T. carinatus $(\mathrm{N})$ & 246.60 & 19.5 & 1.6 \\
\hline FO S. Belemnos $(\mathrm{N})$ & 255.50 & 20.0 & 17.8 \\
\hline LO G. kugleri $(\mathrm{F})$ & 260.30 & 21.8 & 2.7 \\
\hline FO G. kugler (F) & 317.85 & 23.7 & 30.3 \\
\hline LO G. opima $(\mathrm{F})$ & 346.80 & 28.2 & 6.4 \\
\hline LO E. formosus $(\mathrm{N})$ & 519.95 & 40.0 & 12.9 \\
\hline FO D. hesslandii $(\mathrm{N})$ & 606.70 & 42.9 & 7.2 \\
\hline \multicolumn{4}{|l|}{ Holes $805 \mathrm{~B}$ and $805 \mathrm{C}$ : } \\
\hline LO S. heteromorphus (N) & 325.00 & 14.0 & \\
\hline LO S. belemnos $(\mathrm{N})$ & 393.00 & 19.0 & 1.3 \\
\hline LO G. Kugleri (F) & 441.00 & 22.0 & 1.6 \\
\hline LO G. opima $(\mathrm{F})$ & 577.00 & 28.0 & 2.1 \\
\hline
\end{tabular}

through the Pliocene and Quaternary. The dilution effect of abundant calcite in the samples from the interval 5-8 Ma obscures the exact position of the quartz minimum in the upper Miocene, but both records clearly indicate a change in that time from decreasing to increasing quartz abundances.

The record of kaolinite-chlorite/boehmite peak area ratios (Fig. 6H) is rather noisy, with the section older than approximately 5 Ma characterized by single-point peaks rising above a background value of zero. Kaolinite/chlorite abundances are generally higher in the Pliocene and Quaternary section (younger than $5 \mathrm{Ma}$ ), although the effects of dilution by calcite in slightly older sediments may obscure an increase in kaolinite/chlorite abundance defined in the upper Miocene. The only other significant increase in kaolinite/chlorite abundance by multiple data points is a maximum at $13-15 \mathrm{Ma}$, which may result from anomalously small boehmite peaks on those diffractograms.

Illite was not identifiable on the majority of diffractograms, although samples that contain illite are scattered throughout the interval studied (Fig. 6I). Illite-bearing samples cluster near the lower/upper Oligocene boundary (approximately $31 \mathrm{Ma}$ ) and in the lower Miocene (21-18 Ma); illite abundances are consistently high in Pliocene and Quaternary samples (younger than $5 \mathrm{Ma}$ ), with a marked increase in illite abundance over the past $1.5 \mathrm{~m}$.y. As with the records of quartz and kaolinite/chlorite, illite contents may actually begin to increase during the upper Miocene, but calcite dilution in the interval from 5 to $8 \mathrm{Ma}$ obscures any potential signal of that age.

\section{DISCUSSION}

\section{Mineralogy of Eolian Components at Ontong Java Plateau}

The eolian component in sediments of Oligocene to Quaternary age on the OJP consists of smectite, illite, kaolinite/chlorite, quartz, plagioclase, and heulandite (zeolite). This mineral assemblage is consistent with terrigenous assemblages reported previously in modern and ancient sediments of the North Pacific and the equatorial Pacific. As discussed in the "Introduction" section (this chapter), previous studies have attributed the transport of these various components to the Northern Hemisphere westerlies, the northeasterly trades, the southeasterly trades, and variable local winds, all of which can supply dust to OJP. For this reason, the presence/absence of an individual mineral cannot be used a unique indicator of both dust source and transport path; instead, OJP dust provenance is interpreted from two separate lines of evidence: 

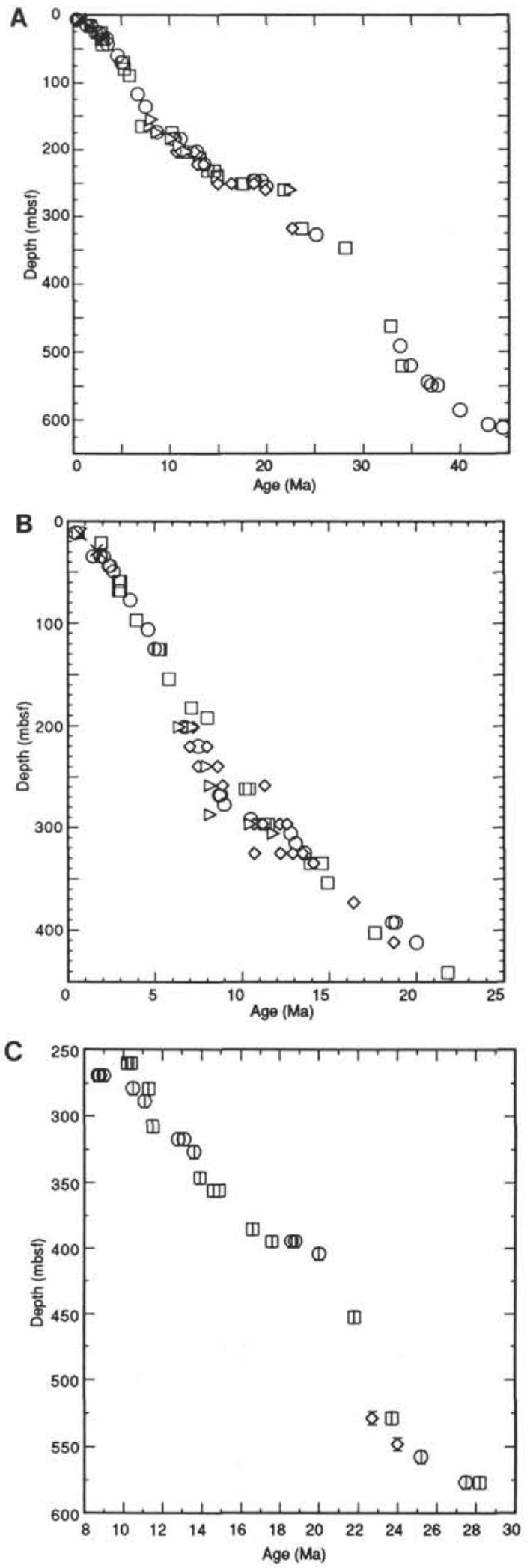

Figure 4. Age/depth plots for Holes 803D (A), 805B (B), and 805C (C). Datums are from Kroenke, Berger, Janecek, et al. (1991). Circles = nannofossils, squares $=$ foraminifers, diamonds $=$ diatoms, triangles $=$ radiolarians, and crosses $=$ magnetostratigraphic reversal boundary. Symbol size approximates sample interval uncertainty. Selected subsets of these datums were used to determine the sedimentation rates shown in Table 2, Appendix B, and Figure 5.
1. Assemblages of minerals that covary on OJPare identified, both by examining the abundance records of individual minerals and by conducting factor analysis of the mineral abundances (Table 3). These assemblages are then compared with assemblages that have been clearly linked to known source regions and wind transport paths by other studies, to identify potential source regions.

2. Temporal variations in the abundances of the OJP mineral assemblages are compared with well-established temporal records of dust MARs deposited beneath the various major wind belts. A wind regime is interpreted to have transported the OJP mineral assemblage if the mineral assemblage and dust MAR exhibit correlative temporal variations.

\section{Definition of Dust Assemblages at Ontong Java Plateau}

The mineral abundance data presented in Figure 6 and discussed in the "Results" section (this chapter), as well as F1 of PCAl (Table 3), suggest that quartz, illite, and kaolinite/chlorite covary through the entire interval examined on OJP. This pattern of covariation is clearly expressed in the smoothed profiles of generalized abundances shown in Figure 7. Each of these minerals has relatively low abundances in the Oligocene and lowest Miocene, and each exhibits a peak in the lower-mid Miocene. For illite, this peak is located at 21-18 Ma, whereas the major Miocene peak for quartz is located at $13-16 \mathrm{Ma}$. Each of these minerals has low abundances for the remainder of the middle and upper Miocene, and then increases to maximum values in the Pliocene and Quaternary. Calcite dilution in the interval 5-8 Ma may obscure the time when each mineral abundance first began to increase but should not affect the general pattern described here, since maximum abundances of each mineral are clearly located in sediments younger than $5 \mathrm{Ma}$.

Plagioclase and smectite abundances also covary with the abundance of quartz/illite/kaolinite/chlorite, although the patterns of covariation change significantly through the interval considered (Fig. 7 and Table 3). The marked increase in plagioclase abundance during the Pliocene and Quaternary closely resembles the correlative increases in quartz/illite/kaolinite/chlorite abundances, suggesting the input of a quartz/illite/chlorite/kaolinite/plagioclase assemblage during the Pliocene and Quaternary (and possibly the latest Miocene). F1 of PCA2 also reflects this association, identifying an important smectite/illite/quartz/plagioclase assemblage that is not distinguished in older sediments. Plagioclase abundances continue to covary with quartz/illite abundances to approximately $17 \mathrm{Ma}$ (F1 of PCA3), and correlate with quartz to some extent in sediments older than $17 \mathrm{Ma}$ (F1 of PCA4). A significant proportion of the plagioclase and quartz variations are inversely correlated in sediments older than $17 \mathrm{Ma}$, however, as indicated by F2 of PCA4. This change is obvious in Figure 7, where plagioclase abundances generally decrease from the Oligocene to the Miocene whereas quartz abundances increase. This change from strong covariation to a combination of positive and inverse covariation supports three conclusions:

1. Additional plagioclase was supplied to OJP independent of the quartz/illite/chlorite/kaolinite/plagioclase assemblage before the middle Miocene.

2. The independent source of plagioclase was an important supplier of plagioclase to OJP during the Oligocene and earliest Miocene.

3. The importance of the independent source of plagioclase gradually decreased relative to the source of the quartz/illite/chlorite/kaolinite/plagioclase assemblage from the Oligocene through the early to middle Miocene.

Smectite's consistently high background abundance suggests the effect of a significant independent source of smectite throughout the interval studied. This interpretation is supported by the results of PCA1 (Table 3), which identifies a monomineralic F3 as the major source of variations in smectite abundance. The strongest association 
A

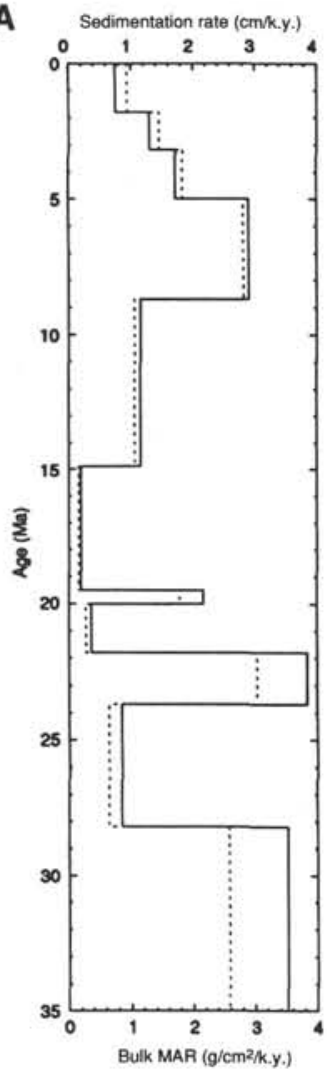

Terrigenous material $(\%)$

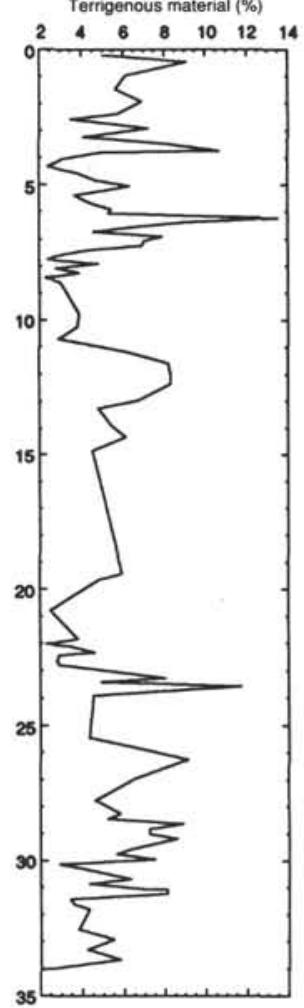

Terrigenous MAR $\left(\mathrm{mg} / \mathrm{cm}^{2} / \mathrm{k} . \mathrm{y}\right.$.)
$0 \quad 100 \quad 200 \quad 300 \quad 400 \quad 500$

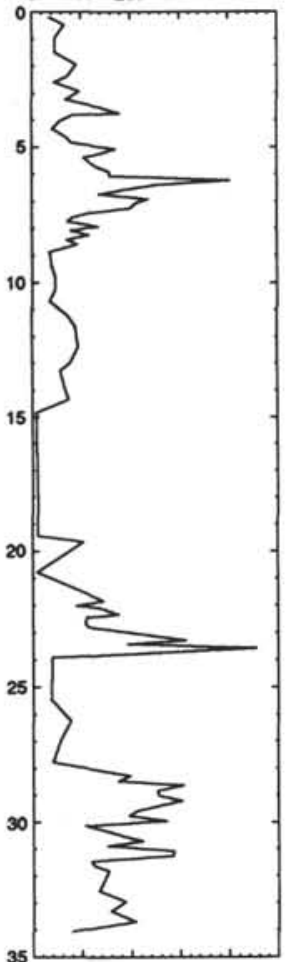

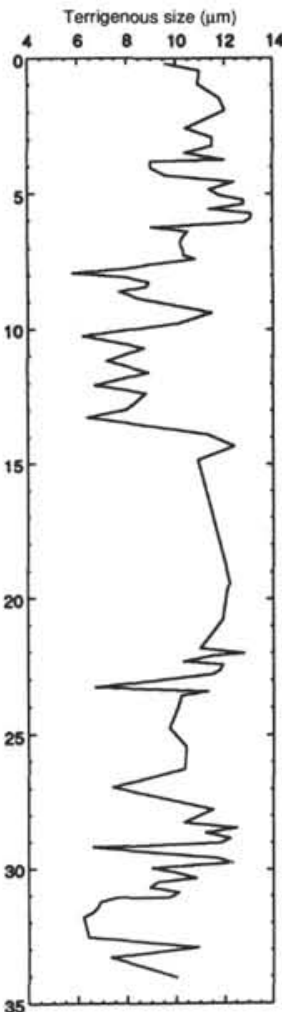

B
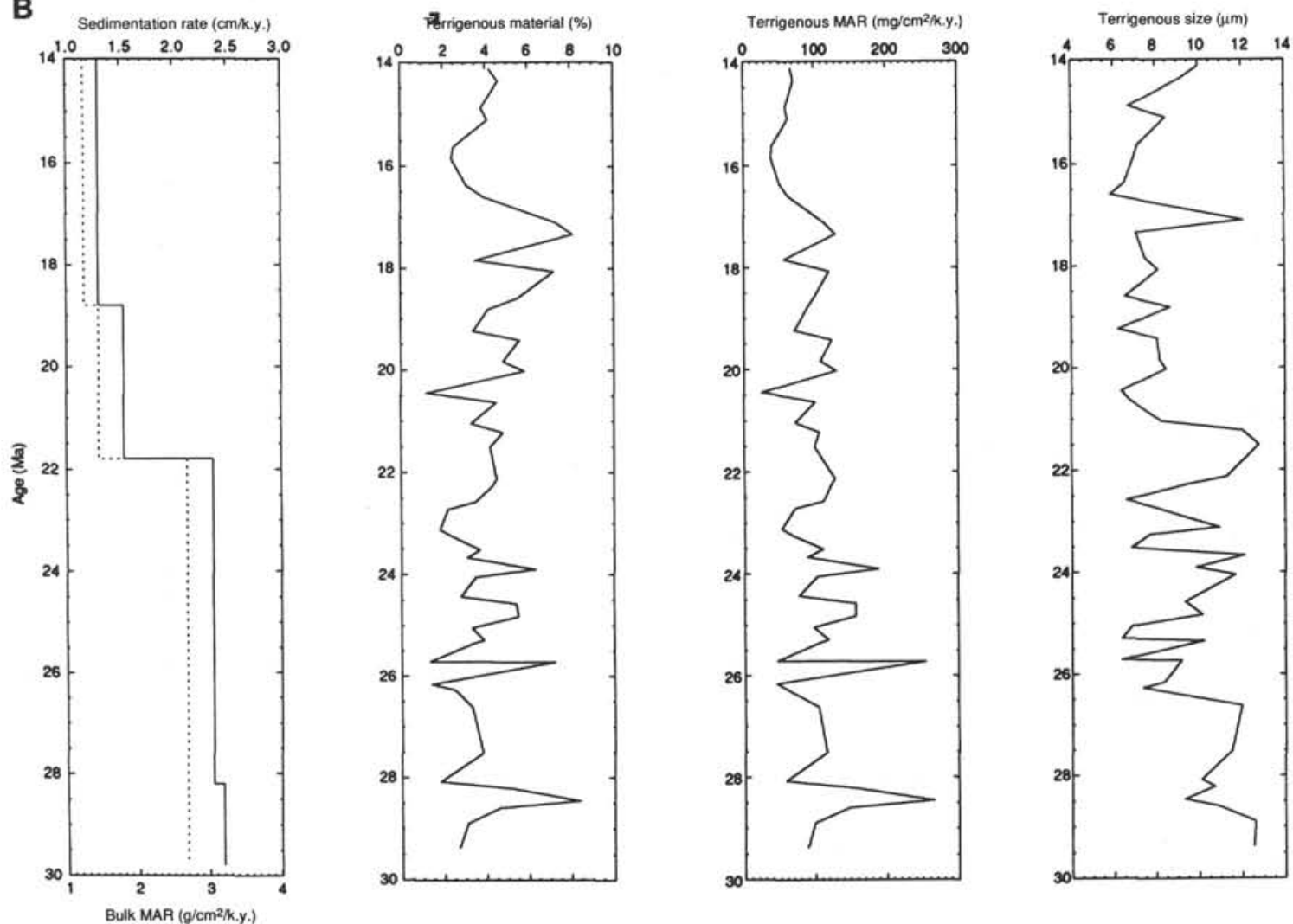

Figure 5. Linear sedimentation rates, bulk mass accumulation rates, terrigenous mass accumulation rates, and terrigenous grain size data for Sites 803 (A) and 805 (B). Control points for sedimentation rates are presented in Table 2. The data used to construct these figures are presented in Appendix A. 
A

Calcium/Boehmite (803)

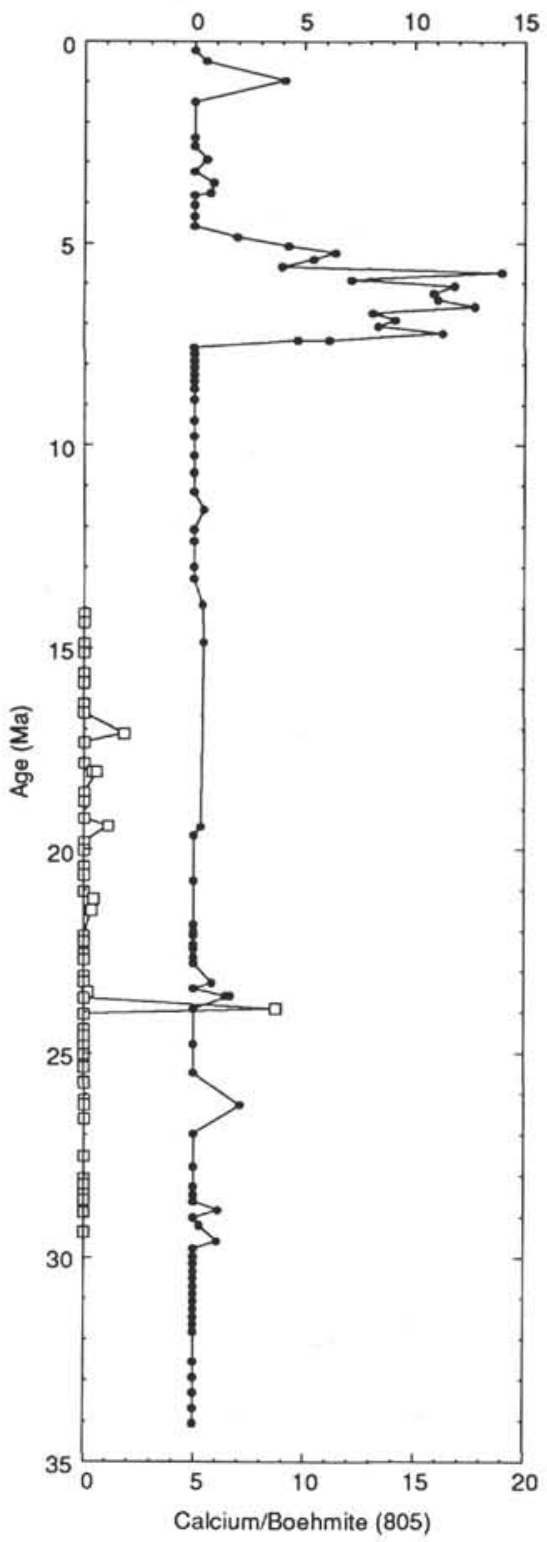

B

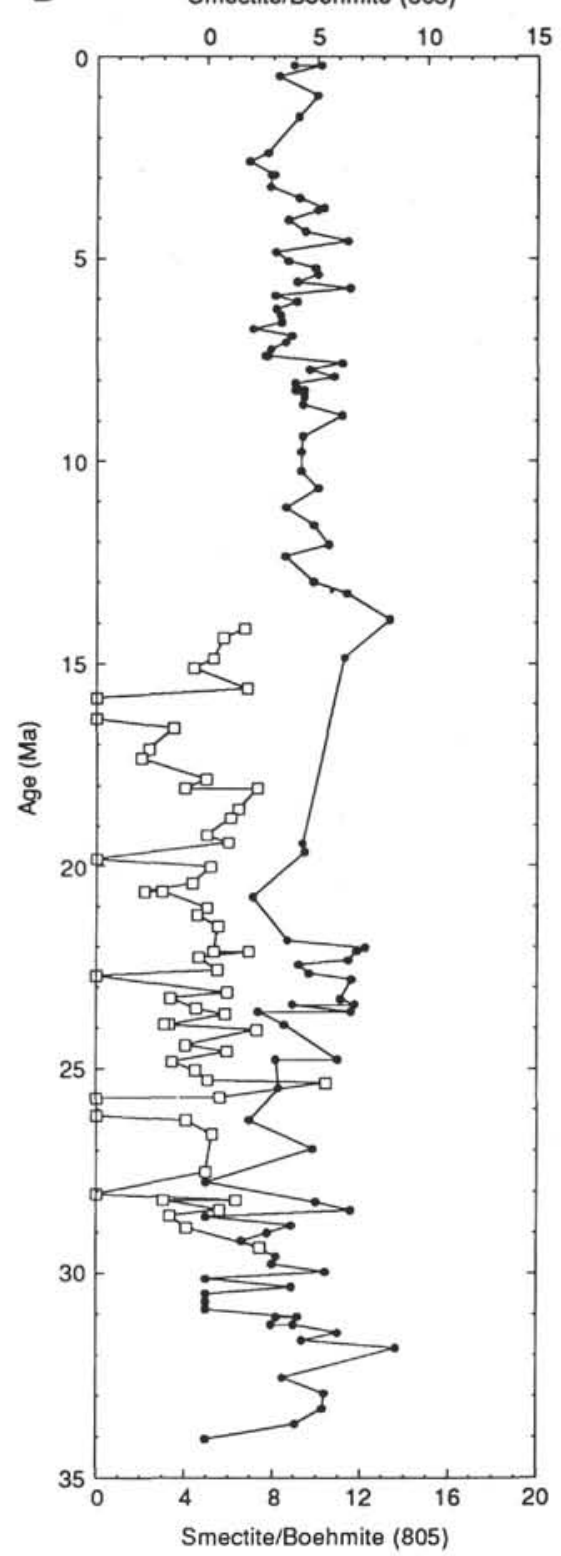

C

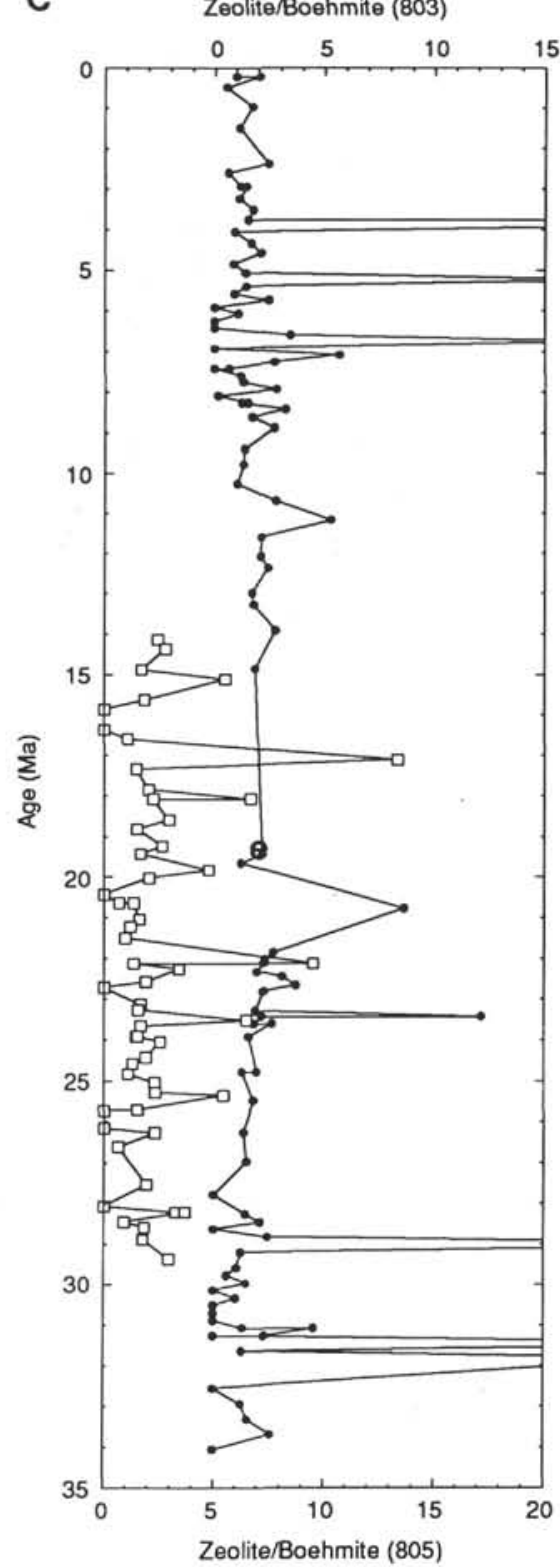

Figure 6. Mineral/boehmite peak area ratios (data presented in Appendix B). Solid circles $=$ Site 803, open square $=$ Site 805 . Note that the $x$-axis scales for the two sites are offset to facilitate plotting but the range of the scales is equivalent. A. Calcite/boehmite. B. Smectite/boehmite. C. Heulandite/boehmite. D. 4.02 plagioclase (P1)/boehmite. E. 3.18-3.20 plagioclase (P2)/boehmite. F. 4.26 quartz (Q1)/boehmite. G. 3.34 quartz (Q2)/boehmite. H. Kaolinite-chlorite/boehmite. I. Illite/boehmite.

between smectite and other minerals is in the interval younger than $5 \mathrm{Ma}$, where abundances of both smectite and the quartz/illite/ kaolinite/chlorite assemblage fluctuate rapidly; this pattern of covariation is clearly identified by F1 of PCA2. Another similarity in the mineral abundance records is the presence of a major abundance peak in smectite and in quartz/illite/kaolinite/chlorite in the middle Miocene (approximately 13-15 Ma; Fig. 7); this feature is recorded by the association of smectite and kaolinite + chlorite in F2 of PCA3.

In summary, covariations in mineral abundance patterns suggest that four distinct minerals/mineral assemblages have been supplied independently to OJP since the Oligocene:

1. A quartz/illite/kaolinite/chlorite assemblage, modified to include plagioclase and minor smectite since the middle Miocene. The impor- tance of this assemblage increased gradually from the Oligocene to a maximum in the middle Miocene, decreased into the late Miocene, and increased significantly through the Pliocene and Quaternary.

2. Smectite, supplied to produce a relatively high and consistent background abundance from the Oligocene to the Quaternary.

3. Plagioclase, supplied from a source whose importance decreased through the early Oligocene, increased significantly in the early late Oligocene, and decreased from the late Oligocene to the early Miocene. The importance of this plagioclase source appears to have remained low since the early Miocene.

4. A zeolite, probably heulandite, supplied to produce a relatively low and consistent background abundance. The importance of the heulandite source increased episodically in the early Oligocene, the early to middle Miocene, and the late Miocene to late Pliocene. 
D

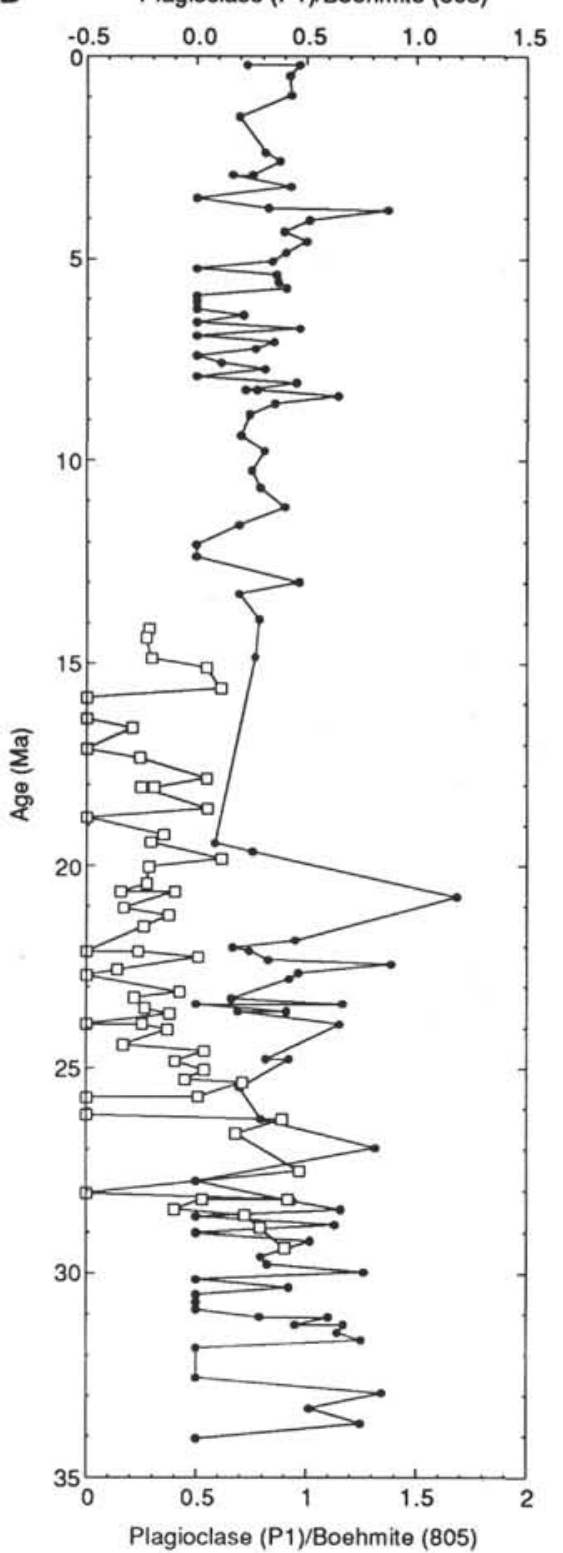

E

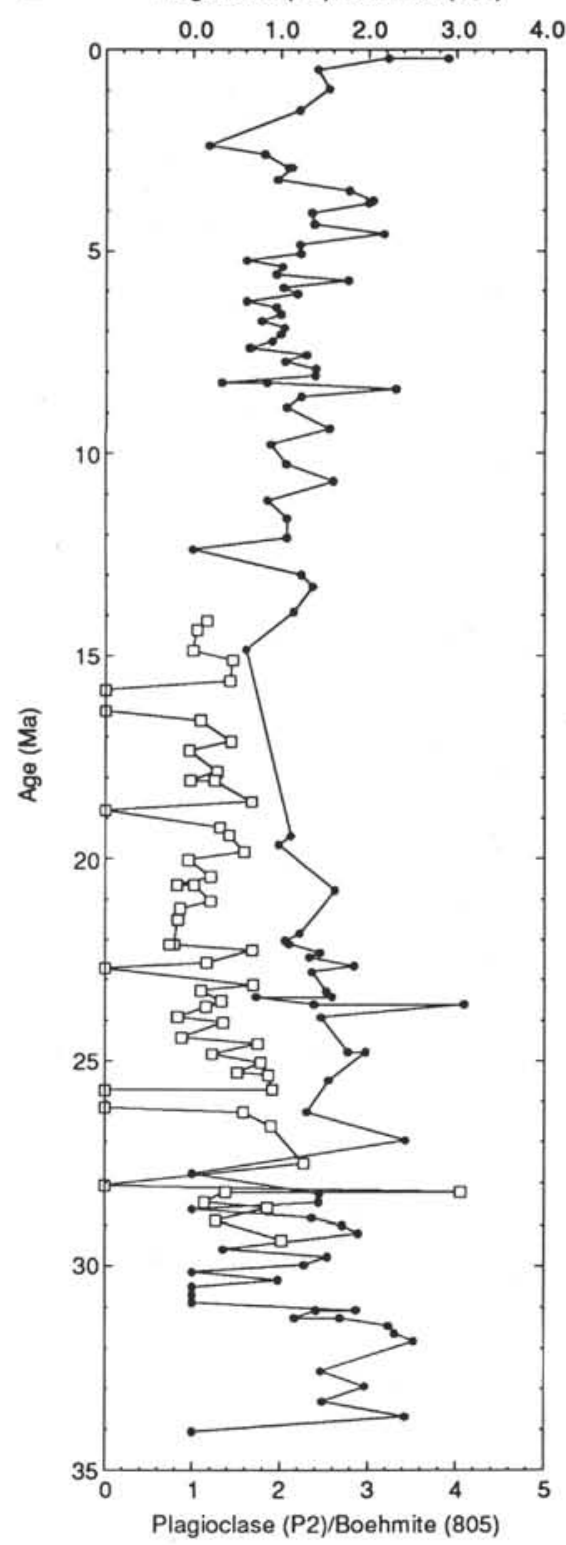

$\mathbf{F}$

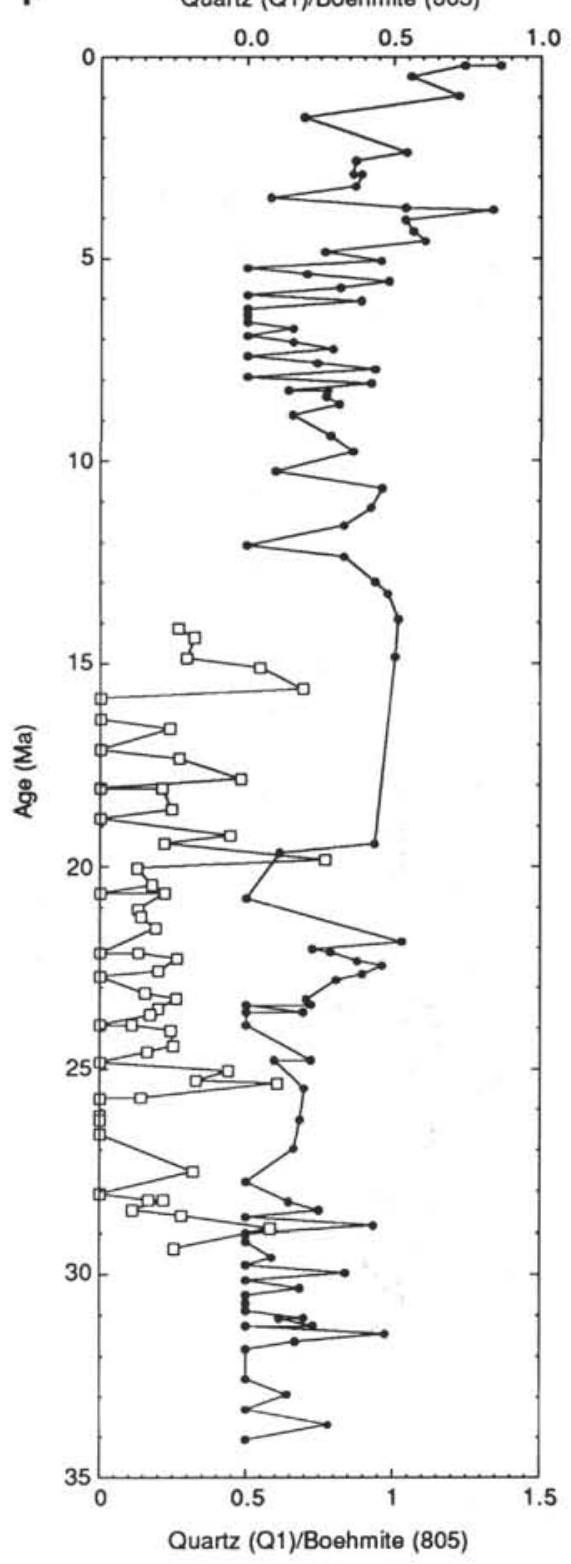

Figure 6 (continued).

\section{Dust Sources and Transport Paths}

Potential sources for these four minerals/mineral assemblages can be identified by comparing the compositions of the four minerals/assemblages to the compositions of Pacific dust derived from modern and well-constrained ancient source regions. The wind regime responsible for transporting each mineral/assemblage can be interpreted from two lines of evidence: the geographic position of the inferred source region relative to OJP, and the similarity in temporal variations of the dust importance and the dust MAR record for that wind pattern. These interpretations are presented below for each of the four minerals/assemblages.

The quartz/illite/kaolinite + chlorite/ $( \pm$ plagioclase and \pm smectite $)$ assemblage contains minerals that develop from a range of subaerial weathering conditions and a range of rock types (Chamley, 1989). This assemblage closely resembles the bulk composition of modern aerosols derived from Asia and collected in the northwest Pacific (Blank et al., 1985), and of Recent, Quaternary, and Cenozoic dust derived from Asia and transported to the northwest Pacific by the prevailing westerlies (Blank et al., 1985; Leinen, 1989; Schramm, 1989; Schoonmaker et al., 1985; LeNotre et al., 1985). On the basis of this compositional similarity, we infer that dust derived from Asia has been supplied to OJP since the Oligocene (recorded as F1 of $\mathrm{PCA} 1$, Table 3 ), with greatest relative importance in the middle Miocene (F1 of PCA3) and the Pliocene through Quaternary (F1 of PCA2). The trajectory by which modern Asian dust is carried to the equatorial central and western Pacific involves transport at high elevation by the westerlies and at lower elevation by the easterlies (Duce et al., 1980; Merrill, 1989; Merrill et al., 1989). The abundance of this mineral assemblage at OJP correlates well with the mass flux record of Asian dust transport to the northwestern Pacific by the westerlies since the Oligocene, exhibiting a similar general increase throughout the Neogene and well-defined increases in the middle Miocene and latest Miocene through Quaternary (Janecek and Rea, 1983; Janecek, 1985; Leinen, 1985; Rea et al., 1985; Rea, 1989). These similarities suggest that source areas beneath the westerlies 
G Quartz (Q2)/Boehmite (803)

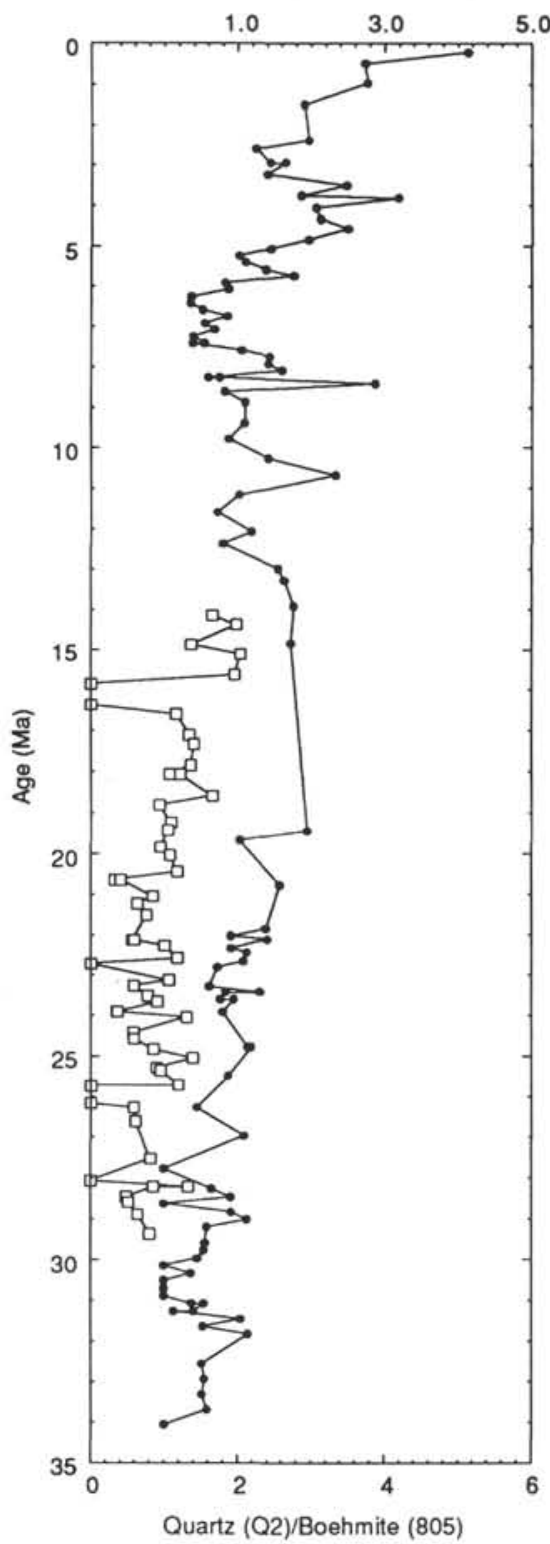

H

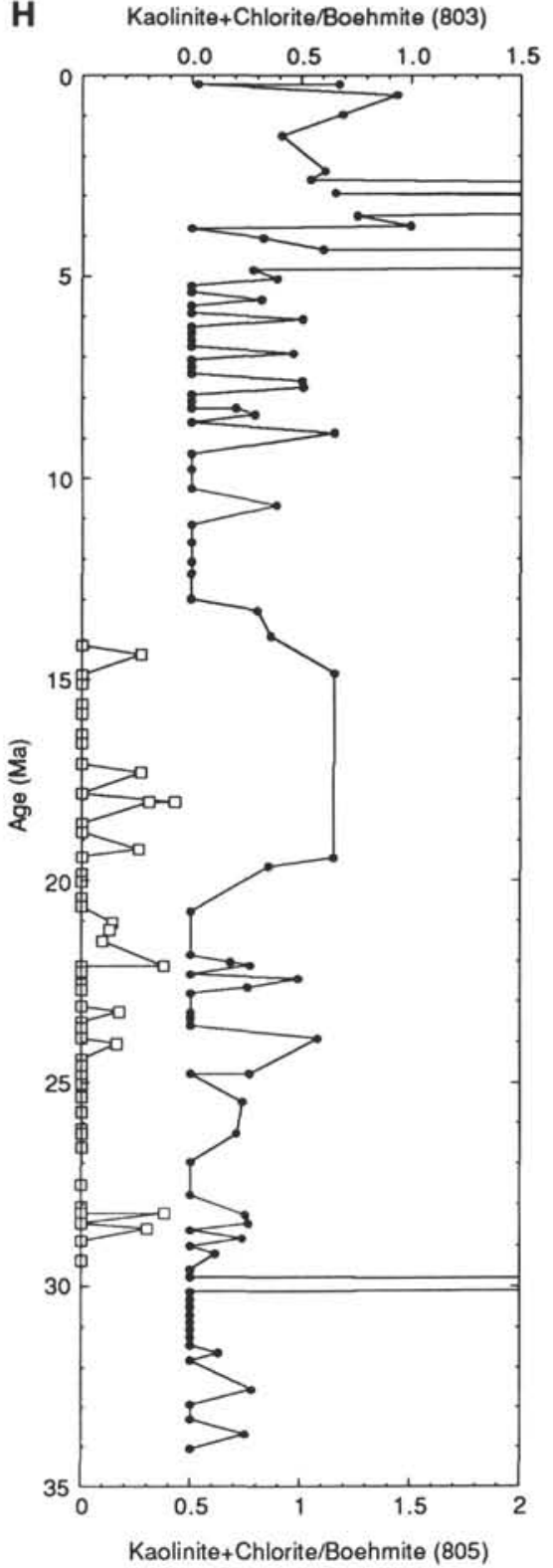

I

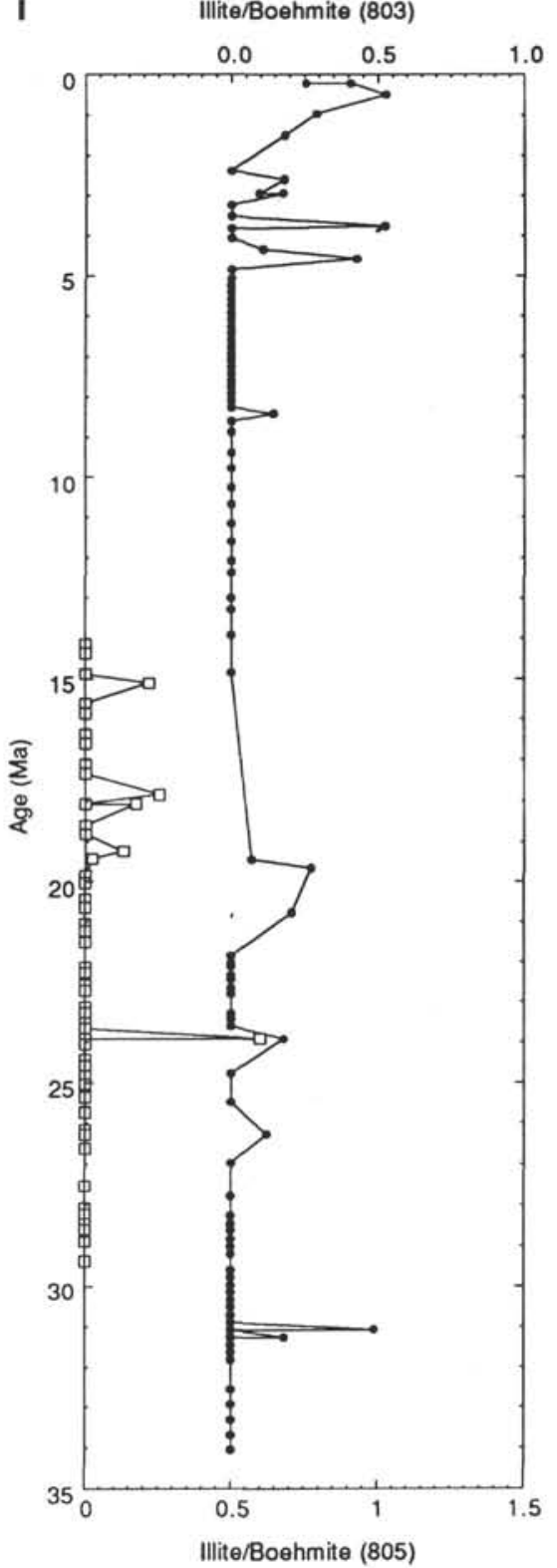

Figure 6 (continued).

have exerted a stronger influence than source areas beneath the easterlies on the composition of the mineral assemblage brought to OJP by the easterlies since the Oligocene.

A separate source supplied plagioclase to OJP from the Oligocene to at least the early Miocene (F2 of PCA4). The importance of this source gradually decreased through that time, with the exception of a major increase during the late Oligocene. The area providing this plagioclase-rich dust cannot be identified uniquely, but the two most obvious alternatives are North and South America, with transport by the easterlies, and local sources to the west, with transport by lowlevel equatorial westerlies. Schoonmaker et al. (1985) have argued that quartz-poor "basic" dust was supplied to DSDP Site 576 by the easterlies before 20-25 Ma; the transport of similar material further west could have supplied additional plagioclase to OJP at that time. The record of plagioclase abundance variations, however, does not exhibit features similar to those observed in MAR records of dust deposited under the influence of the easterlies during the Oligocene to early Miocene. Dust MARs at DSDP Sites 576 (Janecek, 1985),
595 (Schramm and Leinen, 1987), and 597-602 (Bloomstine and Rea, 1986) are low and relatively uniform throughout the Oligocene and lower Miocene, unlike the pattern of decreasing plagioclase abundance at OJP. As a result, comparisons of the plagioclase abundance data and these MAR records cannot be used to argue convincingly for plagioclase supply from the Americas by easterly winds.

No direct data can be used to argue for plagioclase supply to OJP from local sources to the west, but the geologic history of the area during the Oligocene and early Miocene provides a reasonable context for such an interpretation. Subduction-related arc volcanism during the Oligocene extended from Guadalcanal northwestward along the "old North Solomon Arc" of Kroenke (1984), correlative with the supply of abundant plagioclase to OJP. Volcanism ended throughout the arc in the early Miocene, when the supply of plagioclase-rich dust was also decreasing. In summary, the additional plagioclase supply during the Oligocene and early Miocene may have originated from either the Americas or the island arcs to the west. Present data are insufficient to test these two alternatives rigorously, 
but patterns of temporal variation suggest the importance of the more local sources.

Some smectite has been supplied to OJP by way of Asian dust since the late Miocene, as discussed above. To maintain the relatively high and consistent background level of smectite observed throughout the OJP sediments and indicated by F3 of PCA1, however, an additional source must also have supplied a significant amount of smectite (F2 of PCA3 and F3 of PCA4). The potential sources for this material are the same as those considered for plagioclase: the Americas, with transport by means of the easterlies, and local sources to the west, with transport by means of the equatorial westerlies. The influence of the smectite source appears to have been relatively uniform from the Oligocene into at least the late Miocene, as shown by the similarity between F3 of PCA 4 and F2 of PCA3. For that reason, the mineralogy (Schoonmaker et al., 1985) and relatively uniform MARs (Bloomstine and Rea, 1986; Schramm and Leinen, 1987) of dust carried by the easterlies compare better to the smectite signal than they did to the plagioclase record. The possibility of smectite supply from the adjacent island arcs cannot be eliminated, however. Smectite is a common product of the subaerial weathering of volcanic source rocks, and can also be formed by early diagenesis of volcanic ash (Chamley, 1989). The time at which pedogenic smectite is formed is controlled by the time at which the parent volcanic rocks enter the zone of weathering, not by the age of initial eruption; as a result, a relatively consistent supply of detrital smectite to OJP from islands to the west would only require the continuous exposure of volcanic source rocks to weathering, not continuous volcanic activity. If the dominant source of smectite at OJP was from the alteration of volcanic ash, however, the relatively consistent abundance of smectite would require a relatively uniform supply of volcanic ash through time. Subduction-related volcanism ceased in the early Miocene on islands west of OJP (Kroenke, 1984), suggesting that the supply of volcanic ash was not relatively uniform from the Oligocene to the Recent. Instead, appropriate volcanic rocks have apparently been exposed to weathering on those islands since the Oligocene and early Miocene, with the potential to supply detrital smectite by way of the equatorial westerlies.

Heulandite, the final component of OJP dust, is a zeolite that is commonly produced by in-situ alteration of volcanic ash, although it can also form authigenically in the absence of ash (Mumpton, 1981). The various volcanic arcs of the western Pacific are the most obvious potential suppliers of the volcanic ash now converted to heulandite in OJP sediments. Some of this ash probably originated from the islands immediately adjacent to OJP; for example, Oligocene volcanism along the "old North Solomon Arc" (Kroenke, 1984) may have been the source of the ash now found in the cluster of heulandite-rich upper Oligocene samples at OJP. That occurrence of heulandite is also recorded by the intermediate magnitude of the factor matrix coefficients for heulandite (zeolite) in all factors identified by PCA4. The cessation of volcanism in the "old North Solomon Arc" in the early Miocene, however, implies that other areas must have contributed volcanic ash at other times, especially during the late early to middle Miocene (F4 of PCA3) and the late Miocene to late Pliocene (F4 of PCA1). The sources of such ash are not easily identified, although the increase in heulandite during the late Miocene to late Pliocene includes a time of generally increased volcanism throughout the Pacific (Kennett et al., 1977; Rea and Scheidegger, 1979). Some of the ash may have even originated from eruptions in the northwestern Pacific and followed a transport trajectory similar to that of Asian dust deposited at OJP. Because the heulandite abundances at OJP may reflect the combined input of ash from a number of sources that are geographically widespread, the mineral abundance data alone cannot be used to identify specific source regions for each major input of ash. Such correlations would require detailed geochemical data that are beyond the scope of this study.
Table 3. Results of factor analysis of mineral abundance ratios, including distribution of variance among the four most important factors identified in each case, factor matrix, and interpreted source of each mineral assemblage.

\begin{tabular}{|c|c|c|c|c|}
\hline & FI & $F_{2}$ & F3 & F4 \\
\hline \multicolumn{5}{|c|}{ PCAI: } \\
\hline \multicolumn{5}{|c|}{$\begin{array}{l}\text { Interval analyzed: } 0-34 \mathrm{Ma} \\
N=132 \text { cases }\end{array}$} \\
\hline Variance $(\%)$ & 29.7 & 20.2 & 13.5 & 11.9 \\
\hline \multicolumn{5}{|l|}{ Factor matrix: } \\
\hline Smectite/Boehm & -0.156 & -0.224 & $*-0.864$ & 0.181 \\
\hline Illite/Boehm & $\cdot-0.565$ & 0.272 & 0.428 & 0.060 \\
\hline Kaol+Chl/Boehm & $\cdot-0.630$ & 0.471 & 0.036 & 0.068 \\
\hline Zeolite/Boehm & -0.137 & -0.399 & -0.042 & $\bullet 0.877$ \\
\hline Quartz1/Boehm & $*-0.775$ & 0.057 & -0.154 & 0.085 \\
\hline Plag1/Boehm & -0.290 & $*-0.807$ & 0.234 & 0.066 \\
\hline Quartz2/Boehm & $\cdot-0.856$ & 0.143 & -0.180 & 0.013 \\
\hline Plag2/Boehm & -0.446 & -0.658 & 0.182 & 0.356 \\
\hline Source & $\begin{array}{l}\text { Asian } \\
\text { dust }\end{array}$ & $\begin{array}{c}\text { ?Unaltered } \\
\text { local volcanics? }\end{array}$ & $\begin{array}{l}\text { American } \\
\text { dust }\end{array}$ & $\begin{array}{l}\text { ?Altered } \\
\text { local } \\
\text { volcanics? }\end{array}$ \\
\hline \multicolumn{5}{|c|}{$\begin{array}{l}\text { PCA2: } \\
\text { Interval analyzed: } 0-5 \mathrm{Ma} \\
N=16 \text { cases }\end{array}$} \\
\hline Variance (\%) & 42.7 & 17.2 & 15.8 & 11.2 \\
\hline \multicolumn{5}{|l|}{ Factor matrix: } \\
\hline Smectite/Boehm & $*-0.817$ & -0.305 & 0.302 & 0.088 \\
\hline Illite/Boehm & $*-0.737$ & 0.033 & -0.201 & 0.316 \\
\hline Kaol+Chl/Boehm & -0.162 & $*-0.835$ & -0.039 & 0.376 \\
\hline Zeol/Boehm & -0.350 & -0.459 & ${ }^{*} 0.579$ & ${ }^{*} 0.522$ \\
\hline Quartz1/Boehm & $*-0.782$ & 0.108 & -0.359 & 0.344 \\
\hline Plag1/Boehm & -0.356 & -0.335 & $*-0.784$ & 0.253 \\
\hline Quartz2/Boehm & $\cdot-0.802$ & 0.433 & 0.139 & 0.149 \\
\hline Plag2/Boehm & $*-0.824$ & 0.253 & 0.187 & 0.372 \\
\hline Source & $\begin{array}{l}\text { Asian } \\
\text { dust }\end{array}$ & $\begin{array}{l}\text { ?Changes within } \\
\text { Asian dust? }\end{array}$ & $\begin{array}{l}\text { Unaltered vs. } \\
\text { altered local } \\
\text { volcanics }\end{array}$ & $\begin{array}{l}\text { ?Altered } \\
\quad \text { local } \\
\text { volcanics? }\end{array}$ \\
\hline \multicolumn{5}{|c|}{$\begin{array}{l}\text { PCA3: } \\
\text { Interval analyzed: } 7-17 \mathrm{Ma} \\
N=27 \text { cases }\end{array}$} \\
\hline Variance (\%) & 38.6 & 20.5 & 12.9 & 12.1 \\
\hline \multicolumn{5}{|l|}{ Factor matrix: } \\
\hline Smectite/Boehm & -0.213 & $\bullet 0.820$ & -0.143 & 0.085 \\
\hline Illite/Boehm & $*-0.729$ & -0.444 & -0.305 & 0.111 \\
\hline Kaol+Chl/Boehm & -0.194 & $* 0.757$ & -0.164 & 0.172 \\
\hline Zeolite/Boehm & $*-0.522$ & -0.269 & $*-0.439$ & $* 0.611$ \\
\hline Quartz1/Boehm & $*-0.575$ & 0.170 & ${ }^{*} 0.669$ & 0.363 \\
\hline Plag 1/Boehm & $=-0.793$ & -0.210 & $* 0.451$ & 0.076 \\
\hline Quartz2/Boehm & $\cdot-0.860$ & 0.218 & -0.116 & 0.198 \\
\hline Plag2/Boehm & $=-0.707$ & 0.034 & -0.183 & $* 0.607$ \\
\hline Source & $\begin{array}{l}\text { Asian } \\
\text { dust }\end{array}$ & $\begin{array}{l}\text { ?American } \\
\text { dust? }\end{array}$ & $? ? ?$ & $\begin{array}{l}\text { Altered vs. } \\
\text { unaltered local } \\
\text { volcanics }\end{array}$ \\
\hline \multicolumn{5}{|c|}{$\begin{array}{l}\text { PCA4 } \\
\text { Interval analyzed: } 17-34 \mathrm{Ma} \\
N=78 \text { cases }\end{array}$} \\
\hline Variance $(\%)$ & 23.5 & 19.0 & 15.1 & 11.2 \\
\hline \multicolumn{5}{|l|}{ Factor matrix: } \\
\hline Smectite/Boehm & -0.188 & -0.096 & $* 0.782$ & 0.223 \\
\hline Illite/Boehm & 0.244 & -0.182 & -0.514 & $* 0.755$ \\
\hline $\mathrm{Kaol}+\mathrm{Chl} /$ Boehm & -0.173 & $\cdot-0.654$ & -0.250 & 0.138 \\
\hline Zeolite/Boehm & -0.445 & -0.354 & -0.388 & 0.381 \\
\hline Quarzz1/Boehm & $*-0.570$ & -0.259 & 0.080 & 0.266 \\
\hline Plag 1/Boehm & $*-0.665$ & $* 0.542$ & -0.234 & 0.020 \\
\hline Quartz2/Boehm & $*-0.641$ & $\cdot-0.499$ & 0.200 & 0.149 \\
\hline Plag2/Boehm & $*-0.613$ & $* 0.566$ & -0.122 & 0.122 \\
\hline Source & $\begin{array}{l}\text { ?Asian } \\
\text { dust? }\end{array}$ & $\begin{array}{l}\text { ?Unaltered vs. } \\
\text { weathered local } \\
\text { volcanics? }\end{array}$ & $\begin{array}{l}\text { ?American } \\
\text { dust? }\end{array}$ & $\begin{array}{l}\text { ?Asian } \\
\text { dust? }\end{array}$ \\
\hline
\end{tabular}

Notes: Table includes distribution of variance among the four most important factors identified in each case, the factor matrix, and the interpreted source of each mineral assemblage. An asterisk (*) indicates mineral with large factor matrix coefficients, judged to be important in determining the composition and provenance of a factor. $\mathrm{N}=$ number of cases.

\section{Dust Flux, Dust Mineralogy, and Continental Aridity}

In studies of dust records extracted from marine sediments, dust MAR has generally been used as an indicator of aridity in the continental source area of the dust (Pye, 1989; Rea, 1989). The dust MAR record at Sites 803 and 805 , however, is dominated by variations in bulk sedimentation rate, which are largely a function of carbonate production and dissolution. Because of this domination by carbonate, paleoclimatic interpretations of the eolian MAR record are suspect unless both the bulk MAR and the abundance of the eolian 

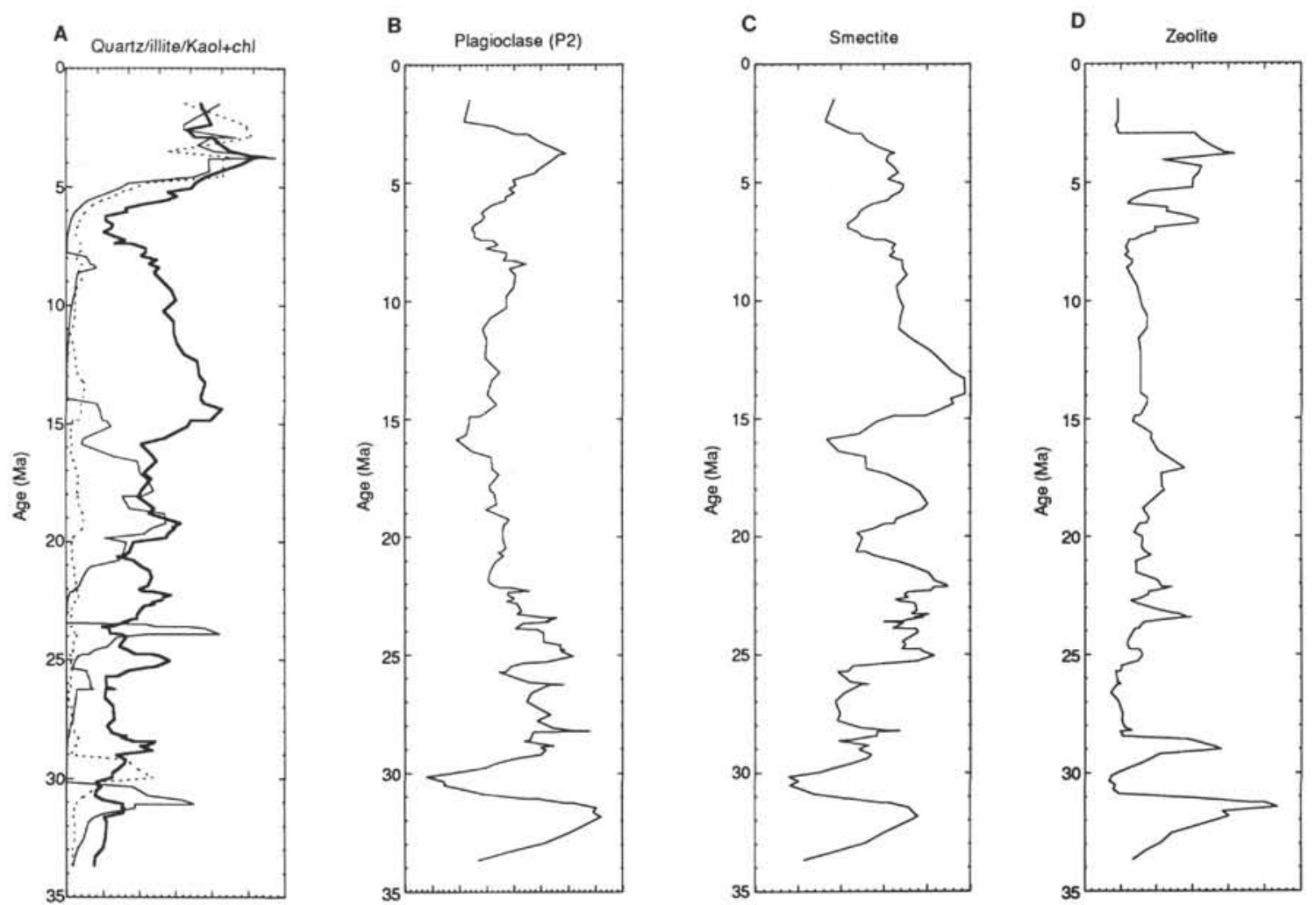

Figure 7. Generalized mineral abundance profiles from OJP. Profiles were generated from the raw data by normalizing each mineral/boehmite value by the greatest mineral/boehmite ratio for that mineral and then smoothing the data with a 9-point filter. A. Components derived from Asia: quartz (thick line), illite (thin solid line), kaolinite/chlorite (dashed line). B. Plagioclase, which was supplied from Asia to the younger sediments and from an important independent source to the older sediments. C. Smectite, predominantly supplied independent of the Asian source, probably from a local source. D. Heulandite, probably supplied from an independent local source.

component increase together. Despite this complication, the dust MAR record from OJP does reflect the effects of multiple dust sources in at least two ways:

1. Dust MARs at OJP are generally $100 \mathrm{mg} / \mathrm{cm}^{2} / \mathrm{k} . \mathrm{y}$. or more, whereas dust MARs at Sites 576 and 598 are lower by more than an order of magnitude. Because Sites 576 and 598 lie upwind of OJP in the westerlies and easterlies, respectively, the flux of dust at OJP caused by those wind systems should be no greater than the fluxes observed at Sites 576 and 598. As a result, the flux at OJP in excess of the fluxes at Sites 576 and 598 must be contributed from local sources that do not influence the sites farther north and east; and

2. Both total MAR and the abundance of the eolian component increase in the peak centered at approximately $22 \mathrm{Ma}$. This event is similar to one observed at GPC-3 in the North Pacific, suggesting that Asian dust temporarily dominated the total dust flux at OJP at that time. Other features in the North Pacific dust MAR record are not observed at OJP, probably because local dust diluted the supply of Asian components.

Within the bulk OJP dust, changes in the importance of the mineralogically defined Asian dust assemblage correlate well with changes in the MAR of North Pacific dust that have generally been ascribed to aridity effects (Janecek and Rea, 1983; Janecek, 1985; Rea, 1989). These include the following: the general increase through the Neogene, attributed to a general increase in aridity accompanying increased polar ice volume; the major middle Miocene peak, attributed to aridification that accompanied a major expansion of the Antarctic ice cap; and the major increase in the Pliocene-Pleistocene, attributed to aridification during Northern Hemisphere glaciation. Similar changes are not observed in the abundance records of plagioclase, smectite, or heulandite, probably because more localized geologic, tectonic, or climatic controls had a significant influence on the supply of dust from these smaller, more proximal, lower latitude source areas.

\section{Grain Size, Dust Mineralogy, and Wind Intensity}

The grain-size profile at OJP does not directly mirror the records of either the Northern Hemisphere westerlies (Rea et al., 1985; Rea, 1989) or the easterlies (Bloomstine and Rea, 1986; Rea, 1989), probably because the dust deposited at OJP since the Oligocene is a complex mixture of dust transported by the westerlies, the easterlies, and local winds, such as the equatorial westerlies. One general similarity, however, is the increase in grain size since approximately $20 \mathrm{Ma}$ at both OJP and the North Pacific sites (DSDP Site 576 and GPC-3). This grain-size increase reflects the increasing importance of Asian dust at OJP during this time, as was also indicated by the mineralogical data. A significant difference between OJP and North Pacific dust, however, is the larger average size of the dust at OJP ( $8-9 \mu \mathrm{m}$ at OJP vs. $2 \mu \mathrm{m}$ at Site 576). This difference may originate in two ways: differences in the instruments used to analyze the two sets of samples and/or supply of coarser grains to OJP from local sources. The grain sizes of the North Pacific dust were measured as the average size within the $1-16 \mu \mathrm{m}$ size interval, whereas the grain sizes of the OJP dust are the average size within the $1-28 \mu \mathrm{m}$ fraction. Because particle volume increases geometrically with increasing grain diameter, the inclusion of only a few larger grains will signifi- 
cantly increase the average size calculated for a sample. The importance of local dust sources, as indicated by the high dust MARs and the abundance of plagioclase, smectite, and heulandite, makes it reasonable to expect that the dust supplied to OJP contains at least a few grains larger than those transported thousands of kilometers to the North Pacific. Because OJP dust is a mixture of materials supplied from multiple sources, by different wind systems, and with very different mineralogies, dust grain size does not accurately reflect the intensity of any single wind regime.

\section{CONCLUSIONS}

On first observation, the records of dust MAR and dust grain size in sediments deposited at OJP since the Oligocene bear little resemblance to well-established records of dust flux and grain size due to transport by the Northern Hemisphere westerlies or equatorial easterlies over that time. Dust mineralogy data, however, can be used to identify distinct minerals or mineral assemblages in the OJP sediments, each with a distinct supply history. One of these assemblages, composed predominantly of quartz, illite, kaolinite, and chlorite, originates in Asia. Variations in the abundance of this assemblage since the Oligocene mirror known changes in the flux of dust transported to the northwest Pacific by the westerlies. Such similarities identify both the source area and the major transport control on this component of the total OJP dust. In contrast, other dust components (plagioclase, smectite) may be contributed from either local or distant source areas, and their transport paths are poorly constrained. In all cases, the correlation of a particular mineral or mineral assemblage to its source region and/or transport pathway becomes mores difficult as the age of the sediment increases.

These results remind us that dust records extracted from marine sediments are most easily interpreted when the dust flux is dominated by a single wind regime and, generally, a single source region; such records can then be considered dust "type sections." In areas that receive dust from multiple sources by way of multiple wind regimes, mineralogic data can be used to subdivide the dust into individual components. The origin and transport record of each dust component can then be examined individually. The insight gained by examining each dust component separately can subsequently be used to understand dust flux and grain-size records that do not agree with those from the "type sections," and thereby improve our understanding of paleoclimate and its dynamics at the boundaries between major wind regimes.

\section{ACKNOWLEDGMENTS}

This work was supported by Leg 130 JOI-USSAC grants to both authors (L.A.K and T.R.J.). The manuscript was reviewed by one anonymous reviewer, and we are grateful for the thoughtful remarks.

\section{REFERENCES*}

Arimoto, R., Duce, R.A., Ray, B.J., Hewitt, A.D., and Williams, J., 1987. Trace elements in the atmosphere of American Samoa: concentrations and deposition to the tropical South Pacific. J. Geophys. Res., 92:8465-8479.

Blank, M., Leinen, M., and Prospero, J.M., 1985. Major Asian eolian inputs indicated by the mineralogy of aerosols and sediments in the western North Pacific. Nature, 314:84-86.

Bloomstine, M.K., and Rea, D.K., 1986. Post-middle Oligocene eolian deposition from the trade winds of the southeast Pacific. In Leinen, M., Rea, D.K., et al., Init. Repts. DSDP, 92: Washington (U.S. Govt. Printing Office), $331-340$.

Chamley, H., 1989. Clay Sedimentology: New York (Springer-Verlag).

Clemens, S.C., and Prell, W.L., 1990. Late Pleistocene variability of Arabian Sea summer-monsoon winds and continental aridity: eolian records from

* Abbreviations for names of organizations and publication titles in ODP reference lists follow the style given in Chemical Abstracts Service Source Index (published by American Chemical Society). the lithogenic component of deep-sea sediments. Paleoceanography, 5:109-145.

Debrabant, P., Krissek, L., Bouquillon, A., and Chamley, H., 1991. Clay mineralogy of Neogene sediments of the western Arabian Sea: mineral abundances and paleoenvironmental implications. In Prell, W.L., Niitsuma, N., et al., Proc. ODP, Sci. Results, 117: College Station, TX (Ocean Drilling Program), 183-196.

Duce, R.A., Unni, C.K., Ray, B., Prospero, J.M., and Merrill, J.T., 1980. Long range transport of soil dust from Asia to the tropical North Pacific: temporal variability. Science, 209:1522-1524.

Gillette, D.A., 1974. On the production of soil wind erosion aerosols having the potential for long range transport. J. Rech. Atmosph., 8:735-744.

Gillette, D.A., Blifford, I.H., Jr., and Fryrear, D.W., 1974. The influence of wind velocity on the size distributions of aerosols generated by wind erosion of soils. J. Geophys. Res., 79:4068-4075.

Gillette, D.A., and Walker, T., 1977. Characteristics of airborne particles produced by wind erosion of sandy soil, high plains of west Texas. Soil Sci., 123:97-110.

Hammond, S.R., Kroenke, L.W., Theyer, F., and Keeling, D.L., 1975. Late Cretaceous and Paleogene paleolatitudes of the Ontong Java Plateau. Nature, 255:46-47.

Janecek, T.R., 1985. Eolian sedimentation in the northwest Pacific Ocean: a preliminary examination of the data from Deep Sea Drilling Project Sites 576 and 578. In Heath, G.R., Burckle, L.H., et al., Init. Repts. DSDP, 86: Washington (U.S. Govt. Printing Office), 589-603.

Janecek, T.R., and Rea, D.K., 1983. Eolian deposition in the northeast Pacific ocean: Cenozoic history of atmospheric circulation. Geol. Soc. Am. Bull., 94:730-738

, 1985 . Quaternary fluctuations in the northern hemisphere trade winds and westerlies. Quat. Res., 24:150-163.

Johnson, L.R., 1976. Particle-size fractionation of eolian dusts during transport and sampling. Mar. Geol., 21:M17-M21.

, 1979. Mineralogical dispersal patterns of North Atlantic deep-sea sediments with particular reference to eolian dusts. Mar. Geol., 29:335-345.

Kennett, J.P., 1982. Marine Geology: New Jersey (Prentice Hall).

Kennett, J.P., McBirney, A.R., and Thunell, R.C., 1977. Episodes of Cenozoic volcanism in the circum-Pacific region. J. Volcanol. Geothermal Res., 2:145-163.

Krissek, L.A., 1984. Continental source area contributions to fine-grained sediments on the Oregon and Washington continental slope. In Stow, D.A.V., and Piper, D.J.W. (Eds.), Fine-Grained Sediments: Deep Water Processes and Facies: Boston (Blackwell Sci.), 363-375.

1989. Bulk mineralogy of nonbiogenic sediments from ODP Sites 642 and 643, Norwegian Sea: implications for sediment provenance and recycling. In Eldholm, O., Thiede, J., et al., Proc. ODP, Sci. Results, 104: College Station, TX (Ocean Drilling Program), 29-39.

Krissek, L.A., and Clemens, S.C., 1991. Mineralogic variations in a Pleistocene high-resolution Eolian record from the Owen Ridge, western Arabian Sea (Site 722): implications for sediment source conditions and monsoon history. In Prell, W.L., Niitsuma, N., et al., Proc, ODP, Sci. Results, 117: College Station, TX (Ocean Drilling Program), 197-213.

Kroenke, L.W., 1984. Cenozoic Tectonic Development of the Southwest Pacific. Tech. Bull., U.N. Econ. Soc. Comm. Asia Pac., Comm. Co-ord. Jt. Prospect Miner. Resour. South Pac. Offshore Areas, 6.

Kroenke, L.W., Berger, W.H., Janecek, T.R., et al., 1991. Proc. ODP, Init. Repts., 130: College Station, TX (Ocean Drilling Program).

Kurnosov, V.B., and Shevchenko, A.Y., 1981. Clay and associated minerals in sediments from the Nauru Basin, Deep Sea Drilling Project Leg 61. In Larson, R.L., Schlanger, S.O., et al., Init. Repts. DSDP, 61: Washington (U.S. Govt. Printing Office), 587-600.

Leinen, M., 1985. Quartz content of northwest Pacific Hole 576A and implications for Cenozoic eolian transport. In Heath, G.R., Burckle, L.H., et al., Init. Repts. DSDP, 86: Washington (U.S. Govt. Printing Office), 581-588.

1989. The Late Quaternary record of atmospheric transport to the northwest: Pacific from Asia. In Leinen, M., and Sarnthein, M. (Eds.), Paleoclimatology and Paleometeorology: Modern and Past Patterns of Global Atmospheric Transport: Boston (Kluwer Academic), 693-732.

Leinen, M., and Sarnthein, M. (Eds.), 1989. Paleoclimatology and Paleometeorology: Modern and Past Patterns of Global Atmospheric Transport: Boston (Kluwer Academic).

Lenotre, N., Chamley, H., and Hoffert, M., 1985. Clay stratigraphy at Deep Sea Drilling Project Sites 576 and 578, Leg 86 (western North Pacific). In Heath, G.R., Burckle, L.H., et al., Init. Repts. DSDP, 86: Washington (U.S. Govt. Printing Office), 571-579. 
Mazzullo, J., and Graham, A.G., 1988. Handbook for Shipboard Sedimentologists. ODP Tech. Note, No. 8.

Merrill, J.T., 1989. Modeling long-range transport using trajectory techniques. In Leinen, M., and Sarnthein, M. (Eds.), Paleoclimatology and Paleometeorology: Modern and Past Patterns of Global Atmospheric Transport: Boston (Kluwer Academic), 207-225.

Merrill, J.T., Uematsu, M., and Bleck, R., 1989. Meteorological analysis of long range transport of mineral aerosols over the Pacific ocean. J. Geophys. Res., 94:8584-8598.

Mumpton, F.A. (Ed.), 1981. Mineralogy and Geology of Natural Zeolites. Mineral. Soc. Am., Rev. in Mineral. Ser., 4.

Parkin, D.W., 1974. Trade winds during the glacial cycles. Proc. R. Soc. London A, 337:73-100,

Parkin, D.W., and Padgham, R.C., 1975. Further studies on trace winds during the glacial cycles. Proc. R. Soc. London A, 346:245-260.

Pewe, T.L. (Ed.), 1981. Desert Dust. Spec. Pap., Geol. Soc. Am., 186.

Prospero, J.M., 1979. Mineral and sea salt aerosol concentrations in various ocean regions. J. Geophys. Res., 84:725-731.

, 1981. Eolian transport to the world ocean. In Emiliani, C. (Ed.), The Sea (Vol. 7): The Oceanic Lithosphere: New York (Wiley), 801-874.

Prospero, J.M., and Bonatti, E., 1969. Continental dust in the atmosphere of the eastern equatorial Pacific. J. Geophys. Res., 74:3362-3371.

Prospero, J.M., Uematsu, M., and Savoie, D., 1989. Mineral aerosol transport to the Pacific Ocean. In Reiley, J.P., and Chester, R. (Eds.), Chemical Oceanography (Vol. 10): San Diego (Academic).

Pye, K., 1987. Aeolian Dust and Dust Deposits: New York (Academic). , 1989. Processes of fine particle formation, dust source regions, and climatic changes. In Leinen, M., and Sarnthein, M. (Eds.), Paleoclimatology and Paleometeorology: Modern and Past Patterns of Global Atmospheric Transport: Boston (Kluwer), 3-30.

Rea, D.K., 1989. Geologic record of atmospheric circulation on tectonic time scales. In Leinen, M., and Sarnthein, M. (Eds.), Paleoclimatology and Paleometeorology: Modern and Past Patterns of Global Atmospheric Transport: Boston (Kluwer), 841-857.

Rea, D.K., and Janecek, T.R., 1981. Mass accumulation rates of the nonauthigenic, inorganic crystalline (eolian) component of deep sea sediments from the western Mid-Pacific Mountains, DSDP Site 463. In Thiede, J., Vallier, T.L., et al., Init. Repts. DSDP, 62: Washington (U.S. Govt. Printing Office), 653-659.

Rea, D.K, Leinen, M., and Janecek, T.R., 1985. Geologic approach to the long-term history of atmospheric circulation. Science, 227:721-725.
Rea, D.K., and Scheidegger, K.F., 1979. Eastern Pacific spreading rate fluctuation and its relation to Pacific area volcanic episodes. J. Volcanol. Geothermal Res., 5:135-148.

Rex, R.W., and Goldberg, E.D., 1958. Quartz contents of pelagic sediments of the Pacific Ocean. Tellus, 10:153-159.

Rex, R.W., Syers, J.K., Jackson, M.L., and Clayton, R.N., 1969. Eolian origin of quartz in soils of Hawaiian Islands and in Pacific sediments. Science, 163:277-279.

Schoonmaker, J., Mackenzie, F.T., Manghnani, M., Schneider, R.C., Kim, D., Weiner, A., and To, J., 1985. Mineralogy and diagenesis: their effect on acoustic and electrical properties of pelagic clays, Deep Sea Drilling Project Leg 86. In Heath, G.R., Burckle, L.H., et al., Init. Repts. DSDP, 86: Washington (U.S. Govt. Printing Office), 549-570.

Schramm, C.T., 1989. Cenozoic climatic variation recorded by quartz and clay minerals in North Pacific sediments. In Leinen, M., and Sarnthein, M. (Eds.), Paleoclimatology and Paleometeorology: Modern and Past Patterns of Global Atmospheric Transport: Boston (Kluwer), 805-839.

Schramm, C.T., and Leinen, M., 1987. Eolian transport to Hole 595A from the Late Cretaceous through the Cenozoic. In Menard, H.W., Natland, J.H., Jordan, T.H., Orcutt, J.A., et al., Init. Repts. DSDP, 91: Washington (U.S. Govt. Printing Office), 469-473.

Terada, K., and Hanzawa, M., 1984. Climate of the North Pacific Ocean. In van Loon, H. (Ed.), World Survey of Climatology (Vol. 15): Climates of the Oceans: New York (Elsevier), 431-504.

Uematsu, M., Duce, R.A., and Prospero, J.M., 1985. Deposition of atmospheric particles in the North Pacific Ocean. J. Atmos. Chem., 3:123-138.

van Andel, T.H., Heath, G.R., and Moore, T.C., 1975. Cenozoic history and paleoceanography of the central equatorial Pacific Ocean. Mem. Geol. Soc. Am., 1413.

Velleman, P.F., and Velleman, A.Y., 1988. Data Desk Handbook: Northbrook, IL (Odesta Corp.).

Windom, I.L., 1969. Atmospheric dust records in permanent snow fields: implications to marine sedimentation. Geol. Soc. Am. Bull., 80:761-782.

Date of initial receipt: 2 April 1992

Date of acceptance: 1 September 1992

Ms 130B-004 
APPENDIX A

Depth, age, bulk density (DBD), sedimentation rate (LSR), bulk mass accumulation rate (MAR), terrigenous abundance, terrigenous MAR, and terrigenous size data for each sample from Hole 803D and Holes 805B and 805C

\begin{tabular}{|c|c|c|c|c|c|c|c|c|}
\hline $\begin{array}{l}\text { Core, section, } \\
\text { interval }(\mathrm{cm})\end{array}$ & $\begin{array}{l}\text { Depth } \\
\text { (mbsf) }\end{array}$ & $\begin{array}{l}\text { Age } \\
(\mathrm{Ma})\end{array}$ & $\begin{array}{l}\text { DBD } \\
\left(\mathrm{g} / \mathrm{cm}^{3}\right)\end{array}$ & $\begin{array}{c}\text { LSR } \\
(\mathrm{cm} / \mathrm{k} . \mathrm{y} .)\end{array}$ & $\begin{array}{l}\text { Bulk MAR } \\
\left(\mathrm{g} / \mathrm{cm}^{2} / k . y .\right)\end{array}$ & $\begin{array}{l}\text { Terr. } \\
(\%)\end{array}$ & $\begin{array}{c}\text { Terr. MAR } \\
\left(\mathrm{mg} / \mathrm{cm}^{2} / \mathrm{k} . \mathrm{y} .\right)\end{array}$ & $\begin{array}{l}\text { Size } \\
(\mu \mathrm{m})\end{array}$ \\
\hline \multicolumn{9}{|l|}{ 130-803D- } \\
\hline $1 \mathrm{H}-2,58$ & 2.1 & 0.22 & 0.734 & 0.94 & 0.69 & 5.0 & 34.5 & 9.6 \\
\hline $2 \mathrm{H}-2,58$ & 4.6 & 0.49 & 0.767 & 0.94 & 0.72 & 9.1 & 65.6 & 11.0 \\
\hline $2 \mathrm{H}-5,58$ & 9.1 & 0.97 & 0.822 & 0.94 & 0.77 & 6.1 & 47.1 & 10.9 \\
\hline $3 \mathrm{H}-2,58$ & 14.1 & 1.50 & 0.875 & 0.94 & 0.82 & 5.6 & 46.0 & 11.8 \\
\hline $3 \mathrm{H}-5,58$ & 18.6 & 1.95 & 0.897 & 1.45 & 1.30 & 6.9 & 89.7 & 12.0 \\
\hline $4 \mathrm{H}-3,58$ & 25.1 & 2.39 & 0.871 & 1.45 & 1.26 & 5.7 & 72.0 & 10.9 \\
\hline $4 \mathrm{H}-5,58$ & 28.1 & 2.60 & 0.872 & 1.45 & 1.26 & 3.5 & 44.3 & 10.4 \\
\hline $5 \mathrm{H}-2,5 \mathrm{I}$ & 33.0 & 2.94 & 0.920 & 1.45 & 1.33 & 7.2 & 96.0 & 11.5 \\
\hline $5 \mathrm{H}-5,58$ & 37.6 & 3.24 & 0.918 & 1.83 & 1.68 & 4.1 & 68.9 & 11.5 \\
\hline $6 \mathrm{H}-2,58$ & 42.6 & 3.51 & 0.906 & 1.83 & 1.66 & 8.2 & 136.0 & 10.4 \\
\hline $6 \mathrm{H}-5.58$ & 47.1 & 3.76 & 0.911 & 1.83 & 1.67 & 10.7 & 178.3 & 12.0 \\
\hline $7 \mathrm{H}-2,58$ & 48.2 & 3.82 & 0.925 & 1.83 & 1.69 & 4.9 & 82.9 & 9.0 \\
\hline $7 \mathrm{H}-5,58$ & 52.7 & 4.06 & 0.976 & 1.83 & 1.79 & 3.1 & 55.3 & 9.0 \\
\hline $8 \mathrm{H}-2,58$ & 57.7 & 4.34 & 0.952 & 1.83 & 1.74 & 2.4 & 41.8 & 9.6 \\
\hline $8 \mathrm{H}-5,58$ & 62.2 & 4.58 & 0.944 & 1.83 & 1.73 & 3.8 & 65.7 & 12.4 \\
\hline $9 \mathrm{H}-2.58$ & 67.2 & 4.85 & 0.945 & 1.83 & 1.73 & 4.7 & 81.3 & 11.4 \\
\hline $9 \mathrm{H}-5,58$ & 71.7 & 5.07 & 0.954 & 2.82 & 2.69 & 6.3 & 169.6 & 11.8 \\
\hline $10 \mathrm{H}-2,58$ & 76.7 & 5.24 & 0.997 & 2.82 & 2.81 & 5.0 & 140.6 & 12.8 \\
\hline $10 \mathrm{H}-5,58$ & 81.2 & 5.40 & 1.010 & 2.82 & 2.85 & 3.7 & 105.4 & 12.8 \\
\hline $11 \mathrm{H}-2,58$ & 86.2 & 5.58 & 1.010 & 2.82 & 2.85 & 4.1 & 117.0 & 11.4 \\
\hline $11 \mathrm{H}-5,58$ & 90.7 & 5.74 & 1.010 & 2.82 & 2.84 & 4.6 & 130.7 & 13.1 \\
\hline $12 \mathrm{H}-2,58$ & 95.7 & 5.92 & 1.030 & 2.82 & 2.90 & 5.4 & 156.6 & 13.1 \\
\hline $12 \mathrm{H}-5,58$ & 100.2 & 6.07 & 1.060 & 2.82 & 2.99 & 5.3 & 158.3 & 12.8 \\
\hline $13 \mathrm{H}-2,58$ & 105.2 & 6.25 & 1.060 & 2.82 & 2.99 & 13.5 & 403.1 & 9.0 \\
\hline $13 \mathrm{H}-5,58$ & 109.7 & 6.41 & 1.010 & 2.82 & 2.84 & 8.9 & 253.0 & 10.5 \\
\hline $14 \mathrm{H}-2,58$ & 114.7 & 6.59 & 1.040 & 2.82 & 2.93 & 6.3 & 184.7 & 10.3 \\
\hline $14 \mathrm{H}-5,58$ & 119.2 & 6.75 & 1.050 & 2.82 & 2.96 & 4.6 & 136.2 & 10.2 \\
\hline $15 \mathrm{H}-2,58$ & 124.2 & 6.92 & 1.060 & 2.82 & 2.98 & 7.9 & 235.3 & 10.2 \\
\hline $15 \mathrm{H}-5,58$ & 128.7 & 7.08 & 1.070 & 2.82 & 3.01 & 7.0 & 210.4 & 10.3 \\
\hline $16 \mathrm{H}-2.58$ & 133.7 & 7.26 & 1.030 & 2.82 & 2.91 & 6.9 & 200.7 & 10.3 \\
\hline $16 \mathrm{H}-5,58$ & 138.2 & 7.42 & 1.000 & 2.82 & 2.83 & 4.3 & 121.5 & 10.8 \\
\hline $17 \mathrm{H}-2,58$ & 143.2 & 7.60 & 1.000 & 2.82 & 2.83 & 2.9 & 82.1 & 8.9 \\
\hline 17H-5, 58 & 147.7 & 7.76 & 1.060 & 2.82 & 3.00 & 2.4 & 72.0 & 8.0 \\
\hline $18 \mathrm{H}-2,58$ & 152.7 & 7.93 & 0.996 & 2.82 & 2.81 & 4.8 & 134.8 & 5.8 \\
\hline $18 \mathrm{H}-5,58$ & 157.2 & 8.09 & 1.010 & 2.82 & 2.84 & 2.8 & 79.5 & 7.9 \\
\hline $19 \mathrm{H}-2,58$ & 162.2 & 8.27 & 1.060 & 2.82 & 2.98 & 3.9 & 116.1 & 8.9 \\
\hline $19 \mathrm{H}-5,58$ & 166.7 & 8.43 & 1.080 & 2.82 & 3.06 & 2.3 & 70.3 & 8.8 \\
\hline $20 \mathrm{H}-2,58$ & 171.7 & 8.61 & 1.080 & 2.82 & 3.06 & 3.0 & 91.7 & 7.7 \\
\hline $20 \mathrm{H}-5,58$ & 176.2 & 8.88 & 1.040 & 1.05 & 1.09 & 3.2 & 35.0 & 8.5 \\
\hline $21 \mathrm{H}-2,61$ & 181.2 & & 1.020 & 1.05 & 1.07 & & & \\
\hline $21 \mathrm{H}-2,98$ & 181.6 & 9.39 & 1.030 & 1.05 & 1.08 & 3.6 & 38.9 & 11.5 \\
\hline $21 \mathrm{H}-5,58$ & 185.7 & 9.78 & 1.120 & 1.05 & 1.18 & 3.9 & 45.9 & 10.1 \\
\hline $22 \mathrm{H}-2.58$ & 190.7 & 10.26 & 1.170 & 1.05 & 1.22 & 3.8 & 46.5 & 6.2 \\
\hline $22 \mathrm{H}-5,58$ & 195.2 & 10.69 & 1.150 & 1.05 & 1.21 & 2.9 & 35.0 & 8.7 \\
\hline $23 \mathrm{H}-2,58$ & 200.2 & 11.17 & 1.090 & 1.05 & 1.14 & 6.1 & 69.5 & 7.2 \\
\hline $23 \mathrm{H}-5,58$ & 204.7 & 11.60 & 1.010 & 1.05 & 1.06 & 8.2 & 86.6 & 8.9 \\
\hline $24 \mathrm{H}-2,58$ & 209.7 & 12.08 & 1.050 & 1.05 & 1.10 & 8.3 & 91.1 & 6.7 \\
\hline $24 \mathrm{H}-4,58$ & 212.7 & 12.37 & 1.070 & 1.05 & 1.12 & 8.3 & 93.1 & 8.8 \\
\hline $25 X-2,58$ & 219.2 & 12.99 & 1.090 & 1.05 & 1.15 & 6.7 & 76.8 & 8.0 \\
\hline $25 X-4,58$ & 222.2 & 13.28 & 1.120 & 1.05 & 1.18 & 4.8 & 56.5 & 6.4 \\
\hline $26 \mathrm{X}-2,58$ & 228.9 & 13.92 & 1.150 & 1.05 & 1.21 & 5.4 & 65.4 & 11.3 \\
\hline $26 X-5,58$ & 233.4 & 14.35 & 1.140 & 1.05 & 1.20 & 6.1 & 73.3 & 12.4 \\
\hline $27 X-2,58$ & 238.6 & 14.85 & 1.140 & 0.16 & 0.18 & 4.5 & 8.2 & 10.9 \\
\hline $28 X-1,62$ & 246.5 & 19.45 & 1.210 & 0.16 & 0.19 & 5.9 & 11.4 & 12.2 \\
\hline $28 \mathrm{X}-3.58$ & 249.5 & 19.66 & 1.220 & 1.78 & 2.18 & 4.8 & 104.4 & 12.1 \\
\hline $29 X-2,58$ & 257.6 & 20.78 & 1.330 & 0.27 & 0.36 & 2.5 & 9.0 & 11.9 \\
\hline $29 X-5,58$ & 262.1 & 21.86 & 1.250 & 3.03 & 3.80 & 3.8 & 144.4 & 11.0 \\
\hline $30 X-2,55$ & 267.2 & 22.03 & 1.280 & 3.03 & 3.87 & 2.3 & 89.0 & 12.8 \\
\hline $30 \times-4,48$ & 270.1 & 22.12 & 1.280 & 3.03 & 3.88 & 3.5 & 136.0 & 11.5 \\
\hline $31 X-2,58$ & 276.8 & 22.34 & 1.250 & 3.03 & 3.79 & 4.6 & 174.4 & 10.3 \\
\hline $31 X-4,70$ & 279.9 & 22.45 & 1.260 & 3.03 & 3.81 & 2.9 & 110.4 & 11.9 \\
\hline $32 X-2,66$ & 286.5 & 22.66 & 1.250 & 3.03 & 3.78 & 2.8 & 105.9 & 11.8 \\
\hline $32 X-5,62$ & 290.9 & 22.81 & 1.270 & 3.03 & 3.84 & 2.9 & 111.3 & 11.5 \\
\hline $33 X-2,58$ & 296.2 & & 1.280 & 3.03 & 3.87 & & & \\
\hline $33 X-5,66$ & 300.8 & & 1.230 & 3.03 & 3.74 & & & \\
\hline $34 X-2,53$ & 305.3 & 23.29 & 1.290 & 3.03 & 3.90 & 8.0 & 311.9 & 6.7 \\
\hline $34 X-5,41$ & 309.7 & 23.43 & 1.300 & 3.03 & 3.93 & 4.9 & 192.3 & 11.3 \\
\hline $35 X-2,43$ & 314.9 & 23.60 & 1.280 & 3.03 & 3.89 & 11.7 & 455.3 & 10.2 \\
\hline $35 X-5,30$ & 319.3 & 23.93 & 1.320 & 0.64 & 0.85 & 4.5 & 38.0 & 10.1 \\
\hline $36 \mathrm{X}-2,58$ & 324.8 & 24.78 & 1.320 & 0.64 & 0.84 & 4.4 & 37.1 & 9.7 \\
\hline $36 X-5,58$ & 329.3 & 25.48 & 1.310 & 0.64 & 0.84 & 4.3 & 35.9 & 10.4 \\
\hline $37 \mathrm{X}-2.58$ & 334.4 & 26.27 & 1.300 & 0.64 & 0.83 & 9.1 & 75.7 & 10.3 \\
\hline $37 X-5,58$ & 338.9 & 26.97 & 1.320 & 0.64 & 0.84 & 6.5 & 54.8 & 7.4 \\
\hline $38 X-2,58$ & 344.1 & 27.78 & 1.350 & 0.64 & 0.86 & 4.6 & 39.7 & 11.5 \\
\hline $38 \times-5,58$ & 348.6 & 28.27 & 1.310 & 2.58 & 3.39 & 5.8 & 196.6 & 10.3 \\
\hline $39 X-2,58$ & 353.7 & 28.47 & 1.290 & 2.58 & 3.33 & 5.2 & 173.2 & 12.5 \\
\hline
\end{tabular}


APPENDIX A (continued).

\begin{tabular}{|c|c|c|c|c|c|c|c|c|}
\hline $\begin{array}{l}\text { Core, section, } \\
\text { interval }(\mathrm{cm})\end{array}$ & $\begin{array}{l}\text { Depth } \\
\text { (mbsf) }\end{array}$ & $\begin{array}{l}\text { Age } \\
\text { (Ma) }\end{array}$ & $\begin{array}{l}\text { DBD } \\
\left(\mathrm{g} / \mathrm{cm}^{3}\right)\end{array}$ & $\begin{array}{c}\text { LSR } \\
(\mathrm{cm} / \mathrm{k} . \mathrm{y} .)\end{array}$ & $\begin{array}{l}\text { Bulk MAR } \\
\left(\mathrm{g} / \mathrm{cm}^{2} / \mathrm{k} \cdot \mathrm{y} .\right)\end{array}$ & $\begin{array}{l}\text { Terr. } \\
\text { (\%) }\end{array}$ & $\begin{array}{c}\text { Terr. MAR } \\
\left(\mathrm{mg} / \mathrm{cm}^{2} / \mathrm{k} . \mathrm{y} .\right)\end{array}$ & $\begin{array}{l}\text { Size } \\
(\mu \mathrm{m})\end{array}$ \\
\hline \multicolumn{9}{|l|}{ 130-803D- } \\
\hline $39 X-5,58$ & 358.2 & 28.64 & 1.340 & 2.58 & 3.45 & 8.9 & 306.9 & 11.2 \\
\hline $40 X-2,58$ & 363.4 & 28.84 & 1.350 & 2.58 & 3.49 & 7.2 & 251.5 & 12.2 \\
\hline $40 X-5,58$ & 367.9 & 29.02 & 1.370 & 2.58 & 3.54 & 7.2 & 255.1 & 11.8 \\
\hline $41 X-2,53$ & 373.0 & 29.21 & 1.370 & 2.58 & 3.53 & 8.6 & 303.8 & 6.6 \\
\hline $42 X-2,58$ & 382.8 & 29.59 & 1.290 & 2.58 & 3.33 & 6.3 & 209.8 & 11.7 \\
\hline $42 X-5,58$ & 387.3 & 29.77 & 1.350 & 2.58 & 3.47 & 5.6 & 194.4 & 12.3 \\
\hline $43 X-2,58$ & 392.5 & 29.97 & 1.400 & 2.58 & 3.62 & 7.5 & 271.4 & 9.0 \\
\hline $43 X-5,58$ & 397.0 & 30.14 & 1.410 & 2.58 & 3.65 & 2.9 & 105.8 & 10.0 \\
\hline $44 X-2,58$ & 402.1 & 30.34 & 1.380 & 2.58 & 3.56 & 4.2 & 149.4 & 10.8 \\
\hline $44 X-5,58$ & 406.6 & 30.51 & 1.380 & 2.58 & 3.55 & 5.1 & 181.0 & 9.2 \\
\hline $45 X-2,58$ & 411.8 & 30.71 & 1.370 & 2.58 & 3.54 & 6.3 & 222.8 & 8.9 \\
\hline $45 X-5,58$ & 416.3 & 30.89 & 1.360 & 2.58 & 3.52 & 4.3 & 151.2 & 10.1 \\
\hline $46 X-2,29$ & & 31.07 & & 2.58 & & 6.9 & & 9.7 \\
\hline $46 X-2,52$ & 421.3 & 31.08 & 1.370 & 2.58 & 3.53 & 8.1 & 286.3 & 7.6 \\
\hline $46 X-5,53$ & 425.8 & 31.26 & 1.360 & 2.58 & 3.52 & 8.1 & 284.8 & 6.9 \\
\hline $47 X-2,58$ & 431.1 & 31.46 & 1.350 & 2.58 & 3.47 & 3.4 & 118.1 & 6.8 \\
\hline $47 X-5,58$ & 435.6 & 31.64 & 1.340 & 2.58 & 3.46 & 3.6 & 124.5 & 6.6 \\
\hline $48 X-2,48$ & 440.6 & 31.83 & 1.380 & 2.58 & 3.56 & 4.3 & 153.2 & 6.2 \\
\hline $50 X-2,58$ & 459.6 & 32.56 & 1.360 & 2.58 & 3.50 & 3.8 & 133.0 & 6.4 \\
\hline $51 X-2,58$ & 469.3 & 32.94 & 1.320 & 2.58 & 3.40 & 5.5 & 187.1 & 10.9 \\
\hline $52 X-2,58$ & 479.0 & 33.31 & 1.440 & 2.58 & 3.72 & 4.2 & 156.3 & 7.3 \\
\hline $53 \mathrm{X}-2,58$ & 488.7 & 33.69 & 1.390 & 2.58 & 3.59 & 5.8 & 208.1 & 8.7 \\
\hline $54 X-2,55$ & 498.4 & 34.06 & 1.450 & 2.58 & 3.75 & 2.1 & 78.8 & 10.0 \\
\hline \multicolumn{9}{|l|}{ 130-805B- } \\
\hline $36 X-2,72$ & 332.22 & 14.14 & 1.223 & 1.30 & 1.59 & 4.2 & 66.8 & 10.0 \\
\hline $36 X-4,72$ & 335.22 & 14.37 & 1.185 & 1.30 & 1.54 & 4.6 & 70.9 & 9.2 \\
\hline $37 X-2,72$ & 341.92 & 14.88 & 1.203 & 1.30 & 1.56 & 3.8 & 59.4 & 6.7 \\
\hline $37 X-4,72$ & 344.92 & 15.11 & 1.172 & 1.30 & 1.52 & 4.1 & 62.5 & 8.5 \\
\hline $38 X-2,72$ & 351.62 & 15.63 & 1.238 & 1.30 & 1.61 & 2.5 & 40.2 & 7.2 \\
\hline $38 X-4,72$ & 354.62 & 15.86 & 1.231 & 1.30 & 1.60 & 2.4 & 38.4 & 7.0 \\
\hline $39 X-2,72$ & 361.22 & 16.37 & 1.264 & 1.30 & 1.64 & 3.1 & 50.9 & 6.5 \\
\hline $39 X-4,72$ & 364.22 & 16.60 & 1.231 & 1.30 & 1.60 & 3.9 & 62.4 & 5.8 \\
\hline $40 X-2,63$ & 370.83 & 17.11 & 1.196 & 1.30 & 1.55 & 7.3 & 113.5 & 12.1 \\
\hline $40 X-4,62$ & 373.82 & 17.34 & 1.241 & 1.30 & 1.61 & 8.1 & 130.6 & 7.1 \\
\hline $41 X-2,69$ & 380.49 & 17.85 & 1.248 & 1.30 & 1.62 & 3.5 & 56.8 & 7.5 \\
\hline $41 X-4,70$ & 383.50 & 18.08 & 1.294 & 1.30 & 1.68 & 7.2 & 121.1 & 8.1 \\
\hline $42 X-2,72$ & 390.22 & 18.60 & 1.388 & 1.30 & 1.80 & 5.5 & 99.2 & 6.5 \\
\hline $42 X-4.71$ & 393.21 & 18.82 & 1.360 & 1.60 & 2.18 & 4.1 & 89.2 & 8.7 \\
\hline $43 X-2,72$ & 399.92 & 19.24 & 1.311 & 1.60 & 2.10 & 3.4 & 71.3 & 6.2 \\
\hline $43 X-4,72$ & 402.92 & 19.43 & 1.389 & 1.60 & 2.22 & 5.6 & 124.4 & 8.0 \\
\hline $44 X-2,72$ & 409.52 & 19.84 & 1.414 & 1.60 & 2.26 & 4.8 & 108.6 & 8.2 \\
\hline $44 X-4.72$ & 412.52 & 20.03 & 1.413 & 1.60 & 2.26 & 5.8 & 131.1 & 8.5 \\
\hline $45 X-2.72$ & 419.22 & 20.45 & 1.296 & 1.60 & 2.07 & 1.2 & 24.9 & 6.3 \\
\hline $45 X-4,72$ & 422.22 & 20.64 & 1.410 & 1.60 & 2.26 & 4.5 & 101.5 & 6.8 \\
\hline $46 X-2.72$ & 428.72 & 21.05 & 1.387 & 1.60 & 2.22 & 3.3 & 73.2 & 8.2 \\
\hline $46 X-4.72$ & 431.72 & 21.23 & 1.389 & 1.60 & 2.22 & 4.8 & 106.7 & 12.0 \\
\hline $47 X-1.12$ & 436.12 & 21.51 & 1.484 & 1.60 & 2.37 & 4.2 & 99.7 & 12.8 \\
\hline $48 X-2,72$ & 447.72 & 22.13 & 1.345 & 2.13 & 2.87 & 4.5 & 129.0 & 11.3 \\
\hline $48 X-4,72$ & 450.72 & 22.27 & 1.341 & 2.13 & 2.86 & 4.3 & 122.9 & 9.6 \\
\hline $49 X=2,72$ & 457.32 & 22.58 & 1.518 & 2.13 & 3.23 & 3.5 & 11.3 .1 & 6.6 \\
\hline $49 X-4,72$ & 460.32 & 22.72 & 1.527 & 2.13 & 3.25 & 2.2 & 71.5 & 7.8 \\
\hline \multicolumn{9}{|l|}{$130-805 \mathrm{C}$ - } \\
\hline $50 \mathrm{X}-2,50$ & 469.00 & 23.13 & 1.366 & 2.13 & 2.91 & 1.8 & 52.4 & 10.9 \\
\hline $50 X-4,50$ & 472.00 & 23.27 & 1.350 & 2.13 & 2.87 & 2.4 & 69.0 & 7.7 \\
\hline $51 X-2,50$ & 477.50 & 23.52 & 1.416 & 2.13 & 3.02 & 3.7 & 111.6 & 6.8 \\
\hline $51 X-4,50$ & 480.50 & 23.67 & 1.349 & 2.13 & 2.87 & 3.1 & 89.1 & 12.1 \\
\hline $52 X-1,43$ & 485.63 & 23.91 & 1.407 & 2.13 & 3.00 & 6.3 & 188.8 & 9.8 \\
\hline $52 X-3,43$ & 488.63 & 24.05 & 1.382 & 2.13 & 2.94 & 3.5 & 103.0 & 11.7 \\
\hline $53 X-2,42$ & 496.82 & 24.43 & 1.297 & 2.13 & 2.76 & 2.8 & 77.3 & 10.0 \\
\hline $53 X-4,66$ & 500.06 & 24.58 & 1.370 & 2.13 & 2.92 & 5.4 & 157.5 & 9.3 \\
\hline $54 X-1.78$ & 505.38 & 24.83 & 1.334 & 2.13 & 2.84 & 5.5 & 156.3 & 10.2 \\
\hline $54 X-4.94$ & 510.04 & 25.05 & 1.398 & 2.13 & 2.98 & 3.3 & 98.2 & 6.8 \\
\hline $55 X-1.86$ & 515.06 & 25.29 & 1.437 & 2.13 & 3.06 & 3.9 & 119.4 & 6.3 \\
\hline $55 X-2.80$ & 516.50 & 25.35 & 1.479 & 2.13 & 3.15 & 3.4 & 107.1 & 10.2 \\
\hline $56 \mathrm{X}-1.27$ & 524.17 & 25.71 & 1.650 & 2.13 & 3.52 & 1.3 & 45.7 & 6.3 \\
\hline $56 \times-0,39$ & 524.60 & 25.73 & 1.653 & 2.13 & 3.52 & 7.2 & 253.5 & 9.2 \\
\hline $57 \mathrm{X}-1.22$ & 533.72 & 26.16 & 1.486 & 2.13 & 3.16 & 1.4 & 44.3 & 8.3 \\
\hline $57 X-2,103$ & & 26.27 & & 2.13 & & 2.5 & & 7.3 \\
\hline $58 \mathrm{X}-1,18$ & 543.38 & 26.62 & 1.489 & 2.13 & 3.17 & 3.3 & 104.7 & 12.0 \\
\hline $60 X-1.20$ & 562.80 & 27.53 & 1.433 & 2.13 & 3.05 & 3.8 & 116.0 & 11.5 \\
\hline $61 X-2,70$ & 574.50 & 28.08 & 1.508 & 2.13 & 3.21 & 1.8 & 57.8 & 10.1 \\
\hline $61 X-4,70$ & 577.50 & 28.22 & 1.426 & 2.13 & 3.04 & 5.2 & 158.0 & 10.7 \\
\hline $62 X-1.75$ & 582.75 & 28.46 & 1.488 & 2.13 & 3.17 & 8.4 & 266.2 & 9.3 \\
\hline $62 X-3.75$ & 585.75 & 28.60 & 1.528 & 2.13 & 3.26 & 4.6 & 149.7 & 10.9 \\
\hline $63 X-1,38$ & 592.08 & 28.90 & 1.505 & 2.13 & 3.21 & 3.1 & 99.4 & 12.6 \\
\hline $64 X-1.70$ & 602.00 & 29.37 & 1.563 & 2.13 & 3.33 & 2.7 & 89.9 & 12.5 \\
\hline
\end{tabular}




\section{APPENDIX B}

Mineral abundance data (mineral/boehmite ratios) for samples from Hole 803D and Holes 805B and 805C

\begin{tabular}{|c|c|c|c|c|c|c|c|c|c|c|c|}
\hline $\begin{array}{l}\text { Core, section, } \\
\text { interval }(\mathrm{cm})\end{array}$ & $\begin{array}{l}\text { Depth } \\
\text { (mbsf) }\end{array}$ & $\begin{array}{l}\text { Age } \\
\text { (Ma) }\end{array}$ & $\mathrm{Sm} / \mathrm{B}$ & III/B & $\mathrm{K}+\mathrm{Chl} / \mathrm{B}$ & Zeol/B & Qtzl/B & Plag 1/B & Qtz2/B & Plag $2 / B$ & Calc/B \\
\hline \multicolumn{12}{|l|}{ 130-803D- } \\
\hline $1 \mathrm{H}-2,58$ & 2.1 & 0.22 & 3.946 & 0.257 & 0.676 & 1.000 & 0.865 & 0.230 & 4.135 & 2.905 & 0.000 \\
\hline IH $-2,58$ & 2.1 & 0.22 & 5.197 & 0.409 & 0.030 & 2.061 & 0.742 & 0.470 & 4.152 & 2.227 & 0.000 \\
\hline $2 \mathrm{H}-2,58$ & 4.6 & 0.49 & 3.273 & 0.530 & 0.939 & 0.561 & 0.561 & 0.424 & 2.742 & 1.424 & 0.530 \\
\hline $2 \mathrm{H}-5,58$ & 9.1 & 0.97 & 5.015 & 0.292 & 0.692 & 1.738 & 0.723 & 0.431 & 2.769 & 1.554 & 4.138 \\
\hline $3 \mathrm{H}-2,58$ & 14.1 & 1.50 & 4.183 & 0.183 & 0.415 & 1.159 & 0.195 & 0.195 & 1.915 & 1.220 & 0.000 \\
\hline $3 \mathrm{H}-5,58$ & 18.6 & 1.95 & 0.000 & 0.000 & 0.000 & 17.211 & 0.000 & 0.000 & 2.684 & 2.474 & 0.000 \\
\hline $4 \mathrm{H}-3,58$ & 25.1 & 2.39 & 2.779 & 0.000 & 0.610 & 2.468 & 0.545 & 0.312 & 1.974 & 0.182 & 0.000 \\
\hline $4 \mathrm{H}-5,58$ & 28.1 & 2.60 & 1.926 & 0.182 & 0.545 & 0.636 & 0.372 & 0.380 & 1.248 & 0.818 & 0.000 \\
\hline $5 \mathrm{H}-2,5 \mathrm{I}$ & 33.0 & 2.94 & 3.096 & 0.096 & 5.287 & 1.181 & 0.362 & 0.255 & 1.447 & 1.085 & 0.606 \\
\hline $5 \mathrm{H}-2,51$ & 33.0 & 2.94 & 2.924 & 0.177 & 0.658 & 1.481 & 0.392 & 0.165 & 1.658 & 1.127 & 0.557 \\
\hline $5 \mathrm{H}-5,58$ & 37.6 & 3.24 & 2.899 & 0.000 & 5.022 & 1.146 & 0.371 & 0.427 & 1.404 & 0.966 & 0.000 \\
\hline $6 \mathrm{H}-2,58$ & 42.6 & 3.51 & 4.216 & 0.000 & 0.757 & 1.784 & 0.081 & 0.000 & 2.486 & 1.784 & 0.892 \\
\hline $6 \mathrm{H}-5.58$ & 47.1 & 3.76 & 5.344 & 0.525 & 1.000 & 1.541 & 0.541 & 0.328 & 1.869 & 2.049 & 0.738 \\
\hline $7 \mathrm{H}-2,58$ & 48.2 & 3.82 & 5.065 & 0.000 & 0.000 & 30.161 & 0.839 & 0.871 & 3.194 & 2.000 & 0.000 \\
\hline $7 \mathrm{H}-5,58$ & 52.7 & 4.06 & 3.724 & 0.000 & 0.329 & 0.934 & 0.539 & 0.513 & 2.066 & 1.355 & 0.000 \\
\hline $8 \mathrm{H}-2,58$ & 57.7 & 4.34 & 4.494 & 0.108 & 0.602 & 1.687 & 0.566 & 0.398 & 2.133 & 1.386 & 0.000 \\
\hline $8 \mathrm{H}-5.58$ & 62.2 & 4.58 & 6.429 & 0.429 & 9.196 & 2.143 & 0.607 & 0.500 & 2.500 & 2.179 & 0.000 \\
\hline $9 \mathrm{H}-2,58$ & 67.2 & 4.85 & 3.156 & 0.000 & 0.281 & 0.891 & 0.266 & 0.406 & 1.969 & 1.219 & 1.969 \\
\hline $9 \mathrm{H}-5,58$ & 71.7 & 5.07 & 3.721 & 0.000 & 0.393 & 1.443 & 0.459 & 0.344 & 1.459 & 1.230 & 4.311 \\
\hline $10 \mathrm{H}-2,58$ & 76.7 & 5.24 & 4.959 & 0.000 & 0.000 & 17.000 & 0.000 & 0.000 & 1.020 & 0.612 & 6.449 \\
\hline $10 \mathrm{H}-5.58$ & 81.2 & 5.40 & 5.091 & 0.000 & 0.000 & 1.455 & 0.205 & 0.364 & 1.114 & 1.023 & 5.455 \\
\hline $11 \mathrm{H}-2,58$ & 86.2 & 5.58 & 4.129 & 0.000 & 0.323 & 0.919 & 0.484 & 0.371 & 1.387 & 0.952 & 4.016 \\
\hline $11 \mathrm{H}-5.58$ & 90.7 & 5.74 & 6.545 & 0.000 & 0.000 & 2.500 & 0.318 & 0.409 & 1.773 & 1.773 & 14.000 \\
\hline $12 \mathrm{H}-2,58$ & 95.7 & 5.92 & 3.136 & 0.000 & 0.000 & 0.000 & 0.000 & 0.000 & 0.831 & 1.034 & 7.169 \\
\hline $12 \mathrm{H}-5,58$ & 100.2 & 6.07 & 4.122 & 0.000 & 0.512 & 1.098 & 0.390 & 0.000 & 0.878 & 1.195 & 11.854 \\
\hline $13 \mathrm{H}-2,58$ & 105.2 & 6.25 & 3.184 & 0.000 & 0.000 & 0.000 & 0.000 & 0.000 & 0.367 & 0.612 & 10.898 \\
\hline $13 \mathrm{H}-5,58$ & 109.7 & 6.41 & 3.381 & 0.000 & 0.000 & 0.000 & 0.000 & 0.214 & 0.357 & 0.952 & 11.095 \\
\hline $14 \mathrm{H}-2,58$ & 114.7 & 6.59 & 3.429 & 0.000 & 0.000 & 3.476 & 0.000 & 0.000 & 0.524 & 1.000 & 12.786 \\
\hline $14 \mathrm{H}-5,58$ & 119.2 & 6.75 & 2.137 & 0.000 & 0.000 & 18.020 & 0.157 & 0.471 & 0.863 & 0.784 & 8.157 \\
\hline $15 \mathrm{H}-2,58$ & 124.2 & 6.92 & 3.894 & 0.000 & 0.468 & 0.000 & 0.000 & 0.000 & 0.553 & 1.043 & 9.170 \\
\hline $15 \mathrm{H}-5.58$ & 128.7 & 7.08 & 3.627 & 0.000 & 0.000 & 5.706 & 0.157 & 0.353 & 0.686 & 1.000 & 8.392 \\
\hline $16 \mathrm{H}-2,58$ & 133.7 & 7.26 & 2.951 & 0.000 & 0.000 & 2.756 & 0.293 & 0.268 & 0.390 & 0.902 & 11.317 \\
\hline $16 \mathrm{H}-5,58$ & 138.2 & 7.42 & 2.698 & 0.000 & 0.000 & 0.679 & 0.000 & 0.000 & 0.547 & 0.660 & 6.189 \\
\hline $16 \mathrm{H}-5,58$ & 138.2 & 7.42 & 2.778 & 0.000 & 0.000 & 0.000 & 0.000 & 0.000 & 0.389 & 0.639 & 4.750 \\
\hline $17 \mathrm{H}-2,58$ & 143.2 & 7.60 & 6.183 & 0.000 & 0.507 & 1.197 & 0.239 & 0.113 & 1.056 & 1.296 & 0.000 \\
\hline $17 \mathrm{H}-5,58$ & 147.7 & 7.76 & 4.700 & 0.000 & 0.513 & 1.325 & 0.438 & 0.313 & 1.438 & 1.050 & 0.000 \\
\hline $18 \mathrm{H}-2,58$ & 152.7 & 7.93 & 5.800 & 0.000 & 0.000 & 2.822 & 0.000 & 0.000 & 1.422 & 1.400 & 0.000 \\
\hline $18 \mathrm{H}-5,58$ & 157.2 & 8.09 & 4.030 & 0.000 & 0.000 & 0.152 & 0.424 & 0.455 & 1.606 & 1.394 & 0.000 \\
\hline $19 \mathrm{H}-2,58$ & 162.2 & 8.27 & 4.471 & 0.000 & 0.000 & 1.541 & 0.141 & 0.224 & 0.600 & 0.329 & 0.000 \\
\hline $19 \mathrm{H}-2,58$ & 162.2 & 8.27 & 4.051 & 0.000 & 0.204 & 1.255 & 0.276 & 0.276 & 0.755 & 0.847 & 0.000 \\
\hline $19 \mathrm{H}-5,58$ & 166.7 & 8.42 & 4.438 & 0.146 & 0.292 & 3.250 & 0.271 & 0.646 & 2.875 & 2.313 & 0.000 \\
\hline $20 \mathrm{H}-2,58$ & 171.7 & 8.61 & 4.384 & 0.000 & 0.000 & 1.726 & 0.315 & 0.356 & 0.822 & 1.233 & 0.000 \\
\hline $20 \mathrm{H}-5.58$ & 176.2 & 8.88 & 6.172 & 0.000 & 0.655 & 2.741 & 0.155 & 0.241 & 1.103 & 1.069 & 0.000 \\
\hline $21 \mathrm{H}-2,98$ & 181.6 & 9.39 & 4.381 & 0.000 & 0.000 & 1.393 & 0.286 & 0.202 & 1.095 & 1.560 & 0.000 \\
\hline $21 \mathrm{H}-5,58$ & 185.7 & 9.78 & 4.312 & 0.000 & 0.000 & 1.333 & 0.366 & 0.312 & 0.882 & 0.892 & 0.000 \\
\hline $22 \mathrm{H}-2.58$ & 190.7 & 10.26 & 4.310 & 0.000 & 0.000 & 1.056 & 0.099 & 0.254 & 1.423 & 1.070 & 0.000 \\
\hline $22 \mathrm{H}-5.58$ & 195.2 & 10.69 & 5.098 & 0.000 & 0.390 & 2.805 & 0.463 & 0.293 & 2.341 & 1.610 & 0.000 \\
\hline $23 \mathrm{H}-2.58$ & 200.2 & 11.17 & 3.638 & 0.000 & 0.000 & 5.319 & 0.426 & 0.404 & 1.021 & 0.851 & 0.000 \\
\hline $23 \mathrm{H}-5,58$ & 204.7 & 11.60 & 4.894 & 0.000 & 0.000 & 2.167 & 0.333 & 0.197 & 0.727 & 1.076 & 0.455 \\
\hline $24 \mathrm{H}-2,58$ & 209.7 & 12.08 & 5.577 & 0.000 & 0.000 & 2.115 & 0.000 & 0.000 & 1.192 & 1.077 & 0.000 \\
\hline $24 \mathrm{H}-4,58$ & 212.7 & 12.37 & 3.613 & 0.000 & 0.000 & 2.467 & 0.333 & 0.000 & 0.800 & 0.000 & 0.000 \\
\hline $25 X-2,58$ & 219.2 & 12.99 & 4.894 & 0.000 & 0.000 & 1.742 & 0.439 & 0.470 & -1.561 & 1.242 & 0.000 \\
\hline $25 X-4,58$ & 222.2 & 13.28 & 6.411 & 0.000 & 0.304 & 1.821 & 0.482 & 0.196 & 1.643 & 1.375 & 0.000 \\
\hline $26 X-2,58$ & 228.9 & 13.92 & 8.365 & 0.000 & 0.365 & 2.808 & 0.519 & 0.288 & 1.769 & 1.154 & 0.404 \\
\hline $26 \times-5,58$ & 233.4 & 14.35 & 57.800 & 2.800 & 6.200 & 20.400 & 4.400 & 3.000 & 24.200 & 10.400 & 11.200 \\
\hline $27 X-2.58$ & 238.6 & 14.85 & 6.313 & 0.000 & 0.657 & 1.896 & 0.507 & 0.269 & 1.731 & 0.612 & 0.448 \\
\hline $28 \mathrm{X}-1.62$ & 246.5 & 19.45 & 4.386 & 0.070 & 0.649 & 2.228 & 0.439 & 0.088 & 1.947 & 1.123 & 0.333 \\
\hline $28 \times-3,58$ & 249.5 & 19.66 & 4.484 & 0.274 & 0.355 & 1.258 & 0.113 & 0.258 & 1.032 & 0.984 & 0.000 \\
\hline $29 X-2.58$ & 257.6 & 20.78 & 2.116 & 0.209 & 0.000 & 8.674 & 0.000 & 1.186 & 1.581 & 1.628 & 0.000 \\
\hline $29 X-5.58$ & 262.1 & 21.86 & 3.710 & 0.000 & 0.000 & 2.742 & 0.532 & 0.452 & 1.387 & 1.226 & 0.000 \\
\hline $30 \times-2,55$ & 267.2 & 22.03 & 7.227 & 0.000 & 0.182 & 2.348 & 0.227 & 0.167 & 0.909 & 1.061 & 0.000 \\
\hline $30 X-4,48$ & 270.1 & 22.12 & 6.848 & 0.000 & 0.273 & 2.318 & 0.288 & 0.242 & 1.409 & 1.106 & 0.000 \\
\hline $31 X-2,58$ & 276.8 & 22.34 & 6.468 & 0.000 & 0.000 & 1.987 & 0.380 & 0.329 & 0.911 & 1.456 & 0.000 \\
\hline $31 X-4,70$ & 279.9 & 22.45 & 4.225 & 0.000 & 0.493 & 3.141 & 0.465 & 0.887 & 1.127 & 1.338 & 0.000 \\
\hline $32 X-2,66$ & 286.5 & 22.66 & 4.699 & 0.000 & 0.260 & 3.753 & 0.397 & 0.466 & 1.082 & 1.849 & 0.000 \\
\hline $32 X-5,62$ & 290.9 & 22.81 & 6.615 & 0.000 & 0.000 & 2.288 & 0.308 & 0.423 & 0.731 & 1.365 & 0.000 \\
\hline $34 X-2,53$ & 305.3 & 23.29 & 6.118 & 0.000 & 0.000 & 1.912 & 0.206 & 0.162 & 0.618 & 1.529 & 0.853 \\
\hline $34 X-5,41$ & 309.7 & 23.43 & 6.778 & 0.000 & 0.000 & 12.200 & 0.222 & 0.667 & 1.311 & 1.600 & 0.000 \\
\hline $34 X-5,41$ & 309.7 & 23.43 & 3.946 & 0.000 & 0.000 & 2.216 & 0.000 & 0.000 & 0.838 & 0.730 & 0.000 \\
\hline $35 X-2,43$ & 314.9 & 23.60 & 6.608 & 0.000 & 0.000 & 1.843 & 0.196 & 0.412 & 0.765 & 1.392 & 1.471 \\
\hline $35 X-2,44$ & 314.9 & 23.60 & 2.381 & 0.000 & 0.000 & 2.690 & 0.000 & 0.190 & 0.952 & 3.095 & 1.690 \\
\hline $35 X-5,30$ & 319.3 & 23.93 & 3.582 & 0.182 & 0.582 & 1.618 & 0.000 & 0.655 & 0.800 & 1.473 & 0.000 \\
\hline $36 \mathrm{X}-2,58$ & 324.8 & 24.78 & 6.016 & 0.000 & 0.270 & 1.984 & 0.222 & 0.317 & 1.143 & 1.778 & 0.000 \\
\hline $36 \times-2,58$ & 324.8 & 24.78 & 3.173 & 0.000 & 0.000 & 1.308 & 0.096 & 0.423 & 1.192 & 1.981 & 0.000 \\
\hline $36 X-5,58$ & 329.3 & 25.48 & 3.325 & 0.000 & 0.238 & 1.850 & 0.200 & 0.200 & 0.875 & 1.563 & 0.000 \\
\hline $37 X-2,58$ & 334.4 & 26.27 & 1.975 & 0.123 & 0.210 & 1.370 & 0.185 & 0.296 & 0.444 & 1.309 & 2.111 \\
\hline
\end{tabular}


APPENDIX B (continued).

\begin{tabular}{|c|c|c|c|c|c|c|c|c|c|c|c|}
\hline $\begin{array}{l}\text { Core, section, } \\
\text { interval }(\mathrm{cm})\end{array}$ & $\begin{array}{l}\text { Depth } \\
\text { (mbsf) }\end{array}$ & $\begin{array}{l}\text { Age } \\
(\mathrm{Ma})\end{array}$ & $\mathrm{Sm} / \mathrm{B}$ & III/B & $\mathrm{K}+\mathrm{Chl} / \mathrm{B}$ & Zeol/B & Qtzl/B & Plag 1/B & $\mathrm{Qtz2} / \mathrm{B}$ & Plag2/B & Calc/B \\
\hline \multicolumn{12}{|l|}{ 130-803D- } \\
\hline $37 X-5,58$ & 338.9 & 26.97 & 4.873 & 0.000 & 0.000 & 1.527 & 0.164 & 0.818 & 1.091 & 2.436 & 0.000 \\
\hline $38 X-5,58$ & 348.6 & 28.27 & 5.013 & 0.000 & 0.253 & 1.467 & 0.147 & 0.440 & 0.653 & 1.453 & 0.000 \\
\hline $39 X-2,58$ & 353.7 & 28.47 & 6.589 & 0.000 & 0.268 & 2.143 & 0.250 & 0.661 & 0.911 & 1.446 & 0.000 \\
\hline $40 X-2,58$ & 363.4 & 28.84 & 3.901 & 0.000 & 0.239 & 2.479 & 0.437 & 0.634 & 0.915 & 1.366 & 1.127 \\
\hline $40 X-5,58$ & 367.9 & 29.02 & 2.804 & 0.000 & 0.000 & 26.087 & 0.000 & 0.000 & 1.130 & 1.717 & 0.000 \\
\hline $41 X-2,53$ & 373.0 & 29.21 & 1.633 & 0.000 & 0.114 & 1.266 & 0.000 & 0.519 & 0.582 & 1.899 & 0.278 \\
\hline $42 X-2,58$ & 382.8 & 29.59 & 3.205 & 0.000 & 0.000 & 1.064 & 0.090 & 0.295 & 0.564 & 0.359 & 1.077 \\
\hline $42 X-5,58$ & 387.3 & 29.77 & 3.012 & 0.000 & 0.000 & 0.605 & 0.000 & 0.326 & 0.547 & 1.547 & 0.000 \\
\hline $43 X-2,58$ & 392.5 & 29.97 & 5.459 & 0.000 & 6.329 & 1.506 & 0.341 & 0.765 & 0.459 & 1.282 & 0.000 \\
\hline $44 X-2,58$ & 402.1 & 30.34 & 3.915 & 0.000 & 0.000 & 1.034 & 0.186 & 0.424 & 0.373 & 0.983 & 0.000 \\
\hline $46 X-2,29$ & 421.1 & 31.07 & 4.200 & 0.491 & 0.000 & 1.345 & 0.200 & 0.291 & 0.382 & 1.873 & 0.000 \\
\hline $46 X-2,52$ & 421.3 & 31.08 & 3.208 & 0.000 & 0.000 & 4.585 & 0.113 & 0.604 & 0.547 & 1.415 & 0.000 \\
\hline $46 \times-5,53$ & 425.8 & 31.26 & 2.976 & 0.183 & 0.000 & 2.341 & 0.232 & 0.451 & 0.402 & 1.171 & 0.000 \\
\hline $46 X-5,53$ & 425.8 & 31.26 & 4.000 & 0.000 & 0.000 & 0.000 & 0.000 & 0.672 & 0.131 & 1.689 & 0.000 \\
\hline $47 X-2,58$ & 431.1 & 31.46 & 6.024 & 0.000 & 0.000 & 25.833 & 0.476 & 0.643 & 1.048 & 2.238 & 0.000 \\
\hline $47 X-5,58$ & 435.6 & 31.64 & 4.390 & 0.000 & 0.130 & 1.312 & 0.169 & 0.753 & 0.532 & 2.312 & 0.000 \\
\hline $48 X-2,48$ & 440.6 & 31.83 & 8.647 & 0.000 & 0.000 & 20.824 & 0.000 & 0.000 & 1.147 & 2.529 & 0.000 \\
\hline $50 \mathrm{X}-2,58$ & 459.6 & 32.56 & 3.500 & 0.000 & 0.281 & 0.000 & 0.000 & 0.000 & 0.516 & 1.469 & 0.000 \\
\hline $51 X-2,58$ & 469.3 & 32.94 & 5.423 & 0.000 & 0.000 & 1.282 & 0.141 & 0.846 & 0.551 & 1.974 & 0.000 \\
\hline $52 X-2,58$ & 479.0 & 33.31 & 5.333 & 0.000 & 0.000 & 1.561 & 0.000 & 0.515 & 0.515 & 1.485 & 0.000 \\
\hline $53 X-2,58$ & 488.7 & 33.69 & 4.083 & 0.000 & 0.250 & 2.617 & 0.283 & 0.750 & 0.583 & 2.433 & 0.000 \\
\hline \multicolumn{12}{|l|}{ 130-805B- } \\
\hline $36 X-2,72$ & 332.2 & 14.14 & 6.735 & 0.000 & 0.000 & 2.429 & 0.265 & 0.286 & 1.653 & 1.163 & 0.000 \\
\hline $36 \times-4,72$ & 335.2 & 14.37 & 5.780 & 0.000 & 0.271 & 2.780 & 0.322 & 0.271 & 1.983 & 1.051 & 0.000 \\
\hline $37 X-2,72$ & 341.9 & 14.88 & 5.318 & 0.000 & 0.000 & 1.682 & 0.295 & 0.295 & 1.364 & 1.000 & 0.000 \\
\hline $37 X-4,72$ & 344.9 & 15.11 & 4.436 & 0.218 & 0.000 & 5.509 & 0.545 & 0.545 & 2.036 & 1.455 & 0.000 \\
\hline $38 X-2,72$ & 351.6 & 15.63 & 6.878 & 0.000 & 0.000 & 1.837 & 0.694 & 0.612 & 1.959 & 1.429 & 0.000 \\
\hline $39 \times-4,72$ & 364.2 & 16.60 & 3.522 & 0.000 & 0.000 & 1.075 & 0.239 & 0.209 & 1.164 & 1.090 & 0.000 \\
\hline $40 X-2,63$ & 370.8 & 17.11 & 2.380 & 0.000 & 0.000 & 13.360 & 0.000 & 0.000 & 1.340 & 1.440 & 1.820 \\
\hline $40 X-4,62$ & 373.8 & 17.34 & 2.027 & 0.000 & 0.270 & 1.459 & 0.270 & 0.243 & 1.405 & 0.959 & 0.000 \\
\hline $41 X-2,69$ & 380.5 & 17.85 & 4.987 & 0.253 & 0.000 & 2.027 & 0.480 & 0.547 & 1.360 & 1.280 & 0.000 \\
\hline $41 \times-4,70$ & 383.5 & 18.08 & 4.015 & 0.000 & 0.426 & 6.691 & 0.000 & 0.309 & 1.074 & 0.971 & 0.368 \\
\hline $41 X-4,70$ & 383.5 & 18.08 & 7.308 & 0.173 & 0.308 & 2.231 & 0.212 & 0.250 & 1.212 & 1.250 & 0.577 \\
\hline $42 X-2,72$ & 390.2 & 18.60 & 6.449 & 0.000 & 0.000 & 2.959 & 0.245 & 0.551 & 1.653 & 1.673 & 0.000 \\
\hline $42 X-4,71$ & 393.2 & 18.82 & 6.085 & 0.000 & 0.000 & 1.508 & 0.000 & 0.000 & 0.932 & 0.000 & 0.000 \\
\hline $43 X-2,72$ & 399.9 & 19.24 & 5.000 & 0.130 & 0.259 & 2.667 & 0.444 & 0.352 & 1.093 & 1.315 & 0.000 \\
\hline $43 \mathrm{X}-3,72$ & 402.9 & 19.43 & 6.000 & 0.024 & 0.000 & 1.659 & 0.220 & 0.293 & 1.049 & 1.415 & 1.098 \\
\hline $44 X-2,72$ & 409.5 & 19.84 & 0.000 & 0.000 & 0.000 & 4.769 & 0.769 & 0.615 & 0.949 & 1.590 & 0.000 \\
\hline $44 X-4,72$ & 412.5 & 20.03 & 5.190 & 0.000 & 0.000 & 2.048 & 0.127 & 0.286 & 1.079 & 0.952 & 0.000 \\
\hline $45 X-2,72$ & 419.2 & 20.45 & 4.371 & 0.000 & 0.000 & 0.000 & 0.177 & 0.274 & 1.177 & 1.210 & 0.000 \\
\hline $45 X-4,72$ & 422.2 & 20.64 & 2.188 & 0.000 & 0.000 & 0.698 & 0.000 & 0.156 & 0.323 & 0.823 & 0.000 \\
\hline $45 X-4,72$ & 422.2 & 20.64 & 3.000 & 0.000 & 0.000 & 1.351 & 0.221 & 0.403 & 0.403 & 1.013 & 0.000 \\
\hline $46 X-2,72$ & 428.7 & 21.05 & 5.039 & 0.000 & 0.143 & 1.623 & 0.130 & 0.169 & 0.844 & 1.208 & 0.000 \\
\hline $46 X-4,72$ & 431.7 & 21.23 & 4.581 & 0.000 & 0.129 & 1.194 & 0.140 & 0.376 & 0.634 & 0.860 & 0.441 \\
\hline $47 X-1,12$ & 436.1 & 21.51 & 5.536 & 0.000 & 0.095 & 0.976 & 0.190 & 0.262 & 0.762 & 0.833 & 0.357 \\
\hline $48 X-2,72$ & 447.7 & 22.13 & 5.340 & 0.000 & 0.377 & 9.528 & 0.000 & 0.000 & 0.566 & 0.792 & 0.000 \\
\hline $48 X-2,72$ & 447.7 & 22.13 & 6.934 & 0.000 & 0.000 & 1.355 & 0.132 & 0.237 & 0.592 & 0.737 & 0.000 \\
\hline $48 X-4.72$ & 450.7 & 22.27 & 4.649 & 0.000 & 0.000 & 3.421 & 0.263 & 0.509 & 1.000 & 1.684 & 0.000 \\
\hline $49 X-2.72$ & 457.3 & 22.58 & 5.520 & 0.000 & 0.000 & 1.900 & 0.200 & 0.140 & 1.180 & 1.160 & 0.000 \\
\hline \multicolumn{12}{|l|}{ 130-805C- } \\
\hline $50 X-2,50$ & 469.0 & 23.13 & 5.962 & 0.000 & 0.000 & 1.667 & 0.154 & 0.423 & 1.064 & 1.692 & 0.000 \\
\hline $50 X-4,50$ & 472.0 & 23.27 & 3.370 & 0.000 & 0.174 & 1.554 & 0.261 & 0.217 & 0.587 & 1.098 & 0.000 \\
\hline $51 X-2,50$ & 477.5 & 23.52 & 4.547 & 0.000 & 0.000 & 6.493 & 0.200 & 0.267 & 0.773 & 1.333 & 0.187 \\
\hline $51 X-4.50$ & 480.5 & 23.67 & 5.854 & 0.000 & 0.000 & 1.671 & 0.171 & 0.378 & 0.902 & 1.159 & 0.000 \\
\hline $52 X-1,43$ & 485.6 & 23.91 & 3.333 & 0.600 & 0.000 & 1.467 & 0.000 & 0.000 & 0.356 & 0.822 & 8.756 \\
\hline $52 X-1,43$ & 485.6 & 23.91 & 3.091 & 0.000 & 0.000 & 1.527 & 0.109 & 0.255 & 0.364 & 0.836 & 8.727 \\
\hline $52 X-3,43$ & 488.6 & 24.05 & 7.290 & 0.000 & 0.161 & 2.565 & 0.242 & 0.371 & 1.306 & 1.355 & 0.000 \\
\hline $53 X-2,42$ & 496.8 & 24.43 & 4.063 & 0.000 & 0.000 & 1.917 & 0.250 & 0.167 & 0.583 & 0.875 & 0.000 \\
\hline $53 X-4,66$ & 500.1 & 24.58 & 5.950 & 0.000 & 0.000 & 1.313 & 0.163 & 0.538 & 0.588 & 1.750 & 0.000 \\
\hline $54 X-1.78$ & 505.4 & 24.83 & 3.448 & 0.000 & 0.000 & 1.104 & 0.000 & 0.403 & 0.851 & 1.224 & 0.000 \\
\hline $54 X-4,94$ & 510.0 & 25.05 & 4.512 & 0.000 & 0.000 & 2.317 & 0.439 & 0.537 & 1.390 & 1.780 & 0.000 \\
\hline $55 X-1.86$ & 515.1 & 25.29 & 5.092 & 0.000 & 0.000 & 2.355 & 0.329 & 0.447 & 0.895 & 1.513 & 0.000 \\
\hline $55 X-2.80$ & 516.5 & 25.35 & 10.447 & 0.000 & 0.000 & 5.447 & 0.605 & 0.711 & 0.947 & 1.868 & 0.000 \\
\hline $56 X-1,27$ & 524.2 & 25.71 & 5.632 & 0.000 & 0.000 & 1.544 & 0.140 & 0.509 & 1.193 & 1.912 & 0.000 \\
\hline $57 X-2,103$ & & 26.27 & 4.085 & 0.000 & 0.000 & 2.329 & 0.000 & 0.890 & 0.585 & 1.585 & 0.000 \\
\hline $58 \mathrm{X}-1.18$ & 543.4 & 26.62 & 5.261 & 0.000 & 0.000 & 0.652 & 0.000 & 0.681 & 0.609 & 1.899 & 0.000 \\
\hline $60 X-1.20$ & 562.8 & 27.53 & 4.985 & 0.000 & 0.000 & 1.939 & 0.318 & 0.970 & 0.818 & 2.273 & 0.000 \\
\hline $61 X-4,70$ & 577.5 & 28.22 & 6.361 & 0.000 & 0.000 & 3.278 & 0.167 & 0.917 & 1.333 & 4.056 & 0.000 \\
\hline $61 \times-4,70$ & 577.5 & 28.22 & 3.055 & 0.000 & 0.382 & 3.691 & 0.218 & 0.527 & 0.855 & 1.382 & 0.000 \\
\hline $62 X-1.75$ & 582.8 & 28.46 & 5.613 & 0.000 & 0.000 & 0.913 & 0.113 & 0.400 & 0.488 & 1.138 & 0.000 \\
\hline $62 X-3,75$ & 585.8 & 28.60 & 3.349 & 0.000 & 0.302 & 1.837 & 0.279 & 0.721 & 0.512 & 1.860 & 0.000 \\
\hline $63 X-1,38$ & 592.1 & 28.90 & 4.104 & 0.000 & 0.000 & 1.776 & 0.582 & 0.791 & 0.642 & 1.269 & 0.000 \\
\hline $64 X-1.70$ & 602.0 & 29.37 & 7.451 & 0.000 & 0.000 & 2.961 & 0.255 & 0.902 & 0.804 & 2.020 & 0.000 \\
\hline
\end{tabular}

